\title{
Advancement in the sulfone-based dendrimers: From synthesis to application
}

\author{
Shaziya Khanam, Sunil K. Rai, Ashish K. Tewari \\ Department of Chemistry (Center of Advanced Study), Institute of Science, Banaras Hindu University, \\ Varanasi-221005, Uttar Pradesh, India \\ ${ }^{*}$ Corresponding author: E-mail: ashishtewarichem@gmail.com
}

Received: 08 November 2016, Revised: 29 November 2016 and Accepted: 13 December 2016

DOI: $10.5185 /$ amlett.2017.1609

www.vbripress.com/aml

\begin{abstract}
The development of sulfone-based macromolecules (polymer to dendrimers) has been inspired and prompted by much interesting importance of sulfone chemistry. Literature reveals that dendrimers are more demanding than the polymer in many aspects, because of its unique structural properties. Inspite of increasing importance and applications of dendrimers, it has a lot of hindrance regarding the tedious way of synthesis, which requires large excess of reagent and several problems in isolation. Therefore, time to time several tactics of synthesis has been developed. It was also well known that sulfonylation reaction is not only fast and easy to handle but also aryl sulfonylchloride derivatives are inexpensively available. Nowadays, sulfone-based dendrimers are exponentially expanding its application in disciplines of science which lie in organic synthesis, material sciences, combinatorial chemistry, medicinal chemistry and chemical biology. In this review, we have compiled the types of dendrimer and chiefly focused on the synthesis of sulfone-based dendrimers and their applications, in short. Further, future prospect of sulfone-based dendrimers in various branches of science has been outlined.Copyright @ 2017 VBRI Press.
\end{abstract}

Keywords: Dendrimer, generation, sulfone, sulfonimide, sulphonamide, suzuki cross coupling.

\section{Introduction}

Advancement of organic chemistry has given a lot of method of synthesis (solvent free to metal catalyzed, low temperature to high temperature and photochemical to microwave reaction conditions). These methods have been extensively utilized in a broad range of research areas including natural product synthesis $[\mathbf{1 , 2}]$, material science [3], medicinal [4], biological [5] supramolecular chemistry [6], catalysis [7], coordination chemistry [8] and macromolecule synthesis [9-10]. Moreover, some of the reactions (Suzuki-Miyaura [11], Heck [12], Staudinger [13], Ullman [14,15], Sonogashira [16,17], and click reaction (cycloaddition reaction) $[\mathbf{1 8 - 2 0}]$ ) are very powerful tools for the creation of smart macromolecules i.e. branched dendritic molecules [21], which are now become an exciting area of research. Branched dendritic family includes dendrimers, dendrons, dendrigraft and hyperbranched or HY polymers (Fig. 1) $[22,23]$.

Among branched macromolecules, dendrimers represent a key component because of its unique properties like monodispersity, globularity and multiple end-groups at the periphery of the dendritic framework, which does not show by other branched macromolecules and small molecules. Thus dendrimers are foreseen to deliver extraordinary features, for applications in areas such as cancer therapy, biosensors for diagnostics and light harvesting scaffolds, compared to small and branched macromolecules of the same molecular weight [24]. Inspired by these novel features of dendrimers, it attracted a lot to the polymer scientists to focusing on generating new chemistries that can deliver monodispersed polymers with structural perfections and enhanced functions.

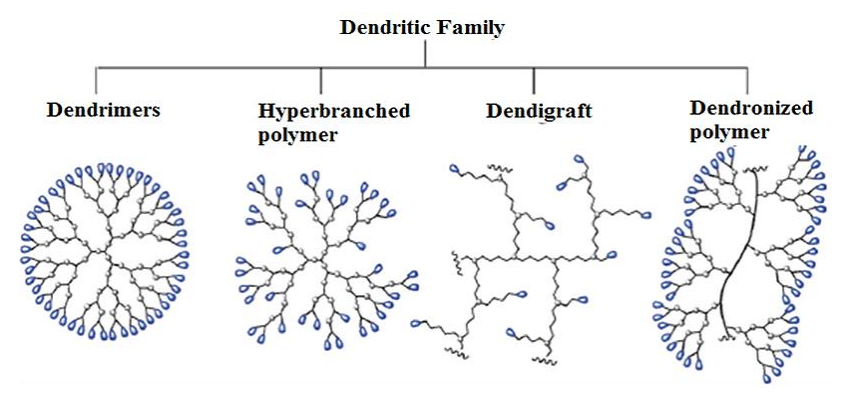

Fig.1: Structural representation of the dendric family.

Flory's, 1941 opened the gate for the synthesis of branched three-dimensional structures $[\mathbf{2 5}, \mathbf{2 6}]$. The synthetic work of such extraordinary molecules was first pioneered by Vögtle in 1978 and termed it "cascade molecules" [27]. A few years later, in the early 1980s, Denkewalter et al. patented the synthesis of L-lysinebased dendrimers upto high generations, but they had not given acomplete characterization of the dendrimers except for size exclusion chromatography (SEC) data [28]. The properties of dendrimers were first examined by 
Tomalia's PAMAM dendrimers and Newkome's arborols [29-31] (unimolecular micelles), then with Meijer's poly(propylene imine) (PPI dendrimers) [32]. Now PAMAM and PPI become most studied and commercialized dendrimers. Nowadays, in the field of synthetic organic chemistry dendrimers become one of the most exciting structures to synthesize and access in comparison to their linear analogs. The field of dendrimers has been continuously reviewed [33-43]. Since an excessive number of dendrimers have continuously been reported. Therefore, we shall shortly describe the dendrimer by diffrent type.

\section{Types of dendrimers}

Dendrimer can be divided on the basis of:

1. Structural design: This category of dendrimer have been constructed by their shape, i.e., spherical [44], dumb-bell $[\mathbf{4 5 , 4 6}]$, tadpole shape $[\mathbf{4 7 , 4 8}]$, snowflake shape [49], multilingual [50] and Janus [51] as shown in Fig. 2.

2. A way of synthesis: This category of dendrimers are classified by their synthetic strategies. The synthetic strategy was started with convergent [33] and divergent [52] method. Now, these come under the conventional growth approach [34]. Further, several strategies had been developed, which came to the accelerated growth approach [53]. The accelerated growth strategies have been divided into two parts as demonstrated in Fig. 5. We briefly explain these strategies.

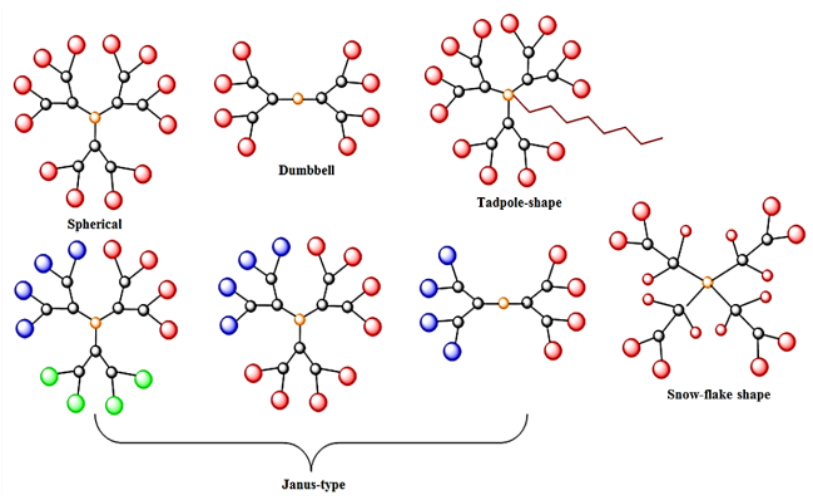

Fig. 2. Different shape of dendrimers.

\section{Conventional synthetic strategy}

(i) Divergent method: In this approach synthesis starts at the core proceeded outwardly to the periphery of the dendrimer.The basic strategy has been demonstrated by cartoon diagram as shown in Fig. 3. The process starts with the coupling between site $\mathrm{C}$ and focal point $\mathrm{F}$ leading to the intermediate with protected periphery indicated by the letter P. Activation of $\mathrm{P}$ at the periphery gave another intermediate with activated periphery indicated by the letter C. Further, coupling with focal point $\mathrm{F}$ of the another branched monomer forming upto second generation dendrimer possessing protected functional group $\mathrm{P}$, which becomes a convenient place for a new active site to react with new branched units to increase generation in dendritic framework.
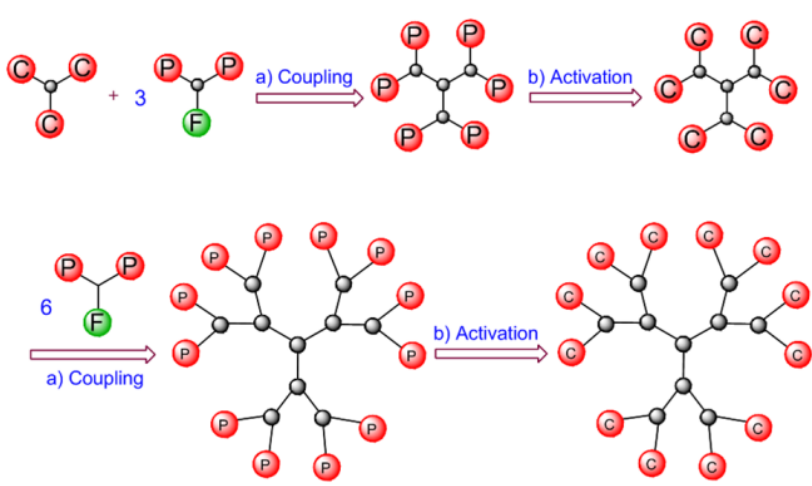

C = Coupling Point; $\mathbf{F}=$ Active, Unprotected functional group $\mathbf{P}=$ Protected, inactive functionality

Fig. 3. Cartoon diagram is representing divergent synthesis.

(ii) Convergent method: In this approach synthesis started at the periphery and proceeded inwardly to the core. It operates inwardly by increasing generation in branched monomer followed by activation and deactivation steps and attached to a core as shown in Fig. 4. Through this method, obtained dendrimers are highly pure and monodispersed.
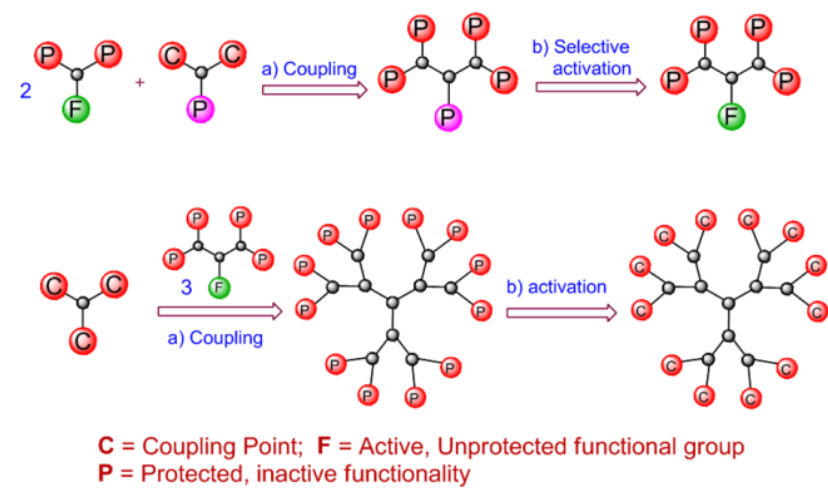

Fig. 4. Cartoon diagram is representing convergent synthesis.

Above two methods have advantage and disadvantage too. Therefore, several other methods have also been developed which are either mixture of the convergent and divergent or some modification in them. Now, these modified methods are called revised traditional strategy. These approaches increase the number of branching in the dendritic framework by decreasing number of synthetic steps but could not eliminate activation and deactivation steps. Several dendrimers have been synthesized using conventional or revised traditional strategies [54-57].

These are as follows:

\section{Revised traditional strategies}

(i) Double-stage convergent growth approach: It combines both convergent and divergent approach and provides new alternative pathway of synthesis, in which both hypercore and dendrons were synthesized parallel through activation and deactivation steps. Further, focal points of dendrons are coupled in a divergent manner to 
the periphery of a hypercore, prepared either by convergent or divergent growth. The synthetic strategy has been shown in Fig. 6. The first successful attempt regarding this approach was made by Wooley [58] et al.

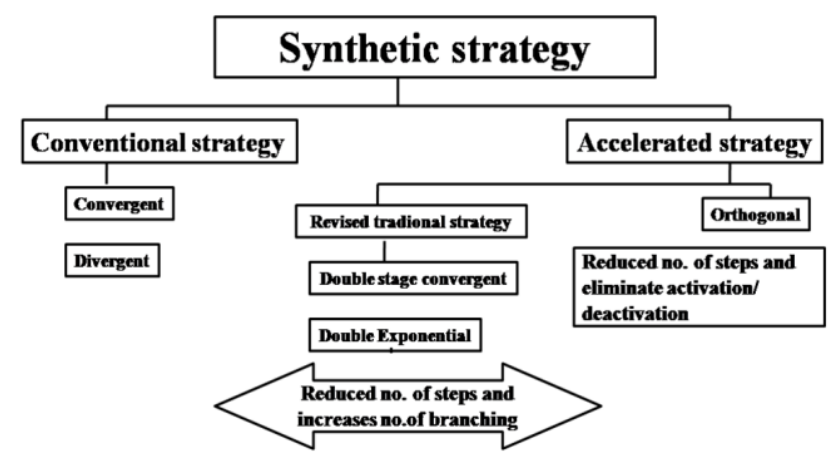

Fig. 5. The flow diagram is showing the synthetic strategies for dendrimers.

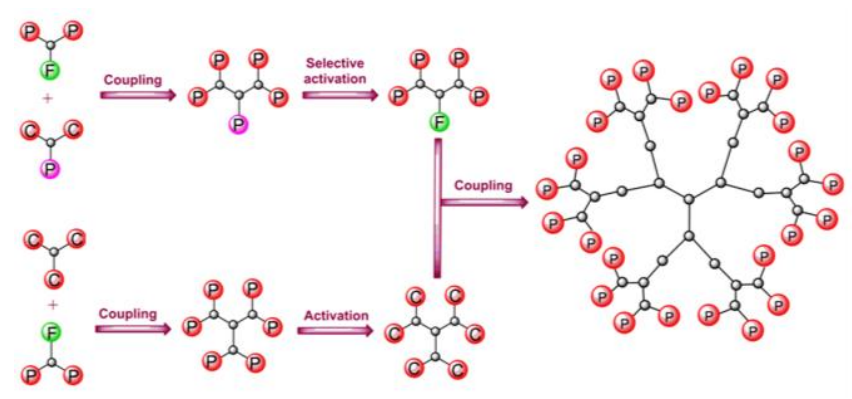

Fig. 6. Cartoon diagram is representing double-stage convergent synthesis.

(ii) Double-exponential dendrimer growth: This approach has been initiated by Moore et al. and developed by Hult et al. [59, 60]. The strategy has been demonstrated in Fig. 7. Two kinds of small branched dendron (activated/deactivated) were utilized. The coupling of these small dendrons was carried out by making activation in them. One dendron is activated selectively, at their focal point while other at the periphery and then coupled together to obtain a higher generation fully protected dendron. These steps were repeated to increase dendrons generation and, in the final step, the focal points of the dendrons are activated and coupled to either tricore or multi-functional core. Thus, The high molecular weight dendrimers were constructed in a lesser number of steps.

So far, scientists have developed newest and simpler routes to construct dendrimers without activation/deactivation steps. Now, these strategy comes under the orthogonal strategy which is accelerated strategy. Further, orthogonal growth concept will be discus.

\section{Orthogonal coupling strategy}

Recently, Zeng and Zimmerman developed an alternative method, that is short period synthesis of thedendrimer, to overcome the difficulties of revised traditional strategy (double stage convergent and double exponential growth approaches) $[60,61]$. In the orthogonal methodology, no activation step is required. Two different kinds of dendrons having different functionality $\left(\mathrm{AB}_{2}\right.$ and $\left.\mathrm{CD}_{2}\right)$ were utilized for increasing branching units.

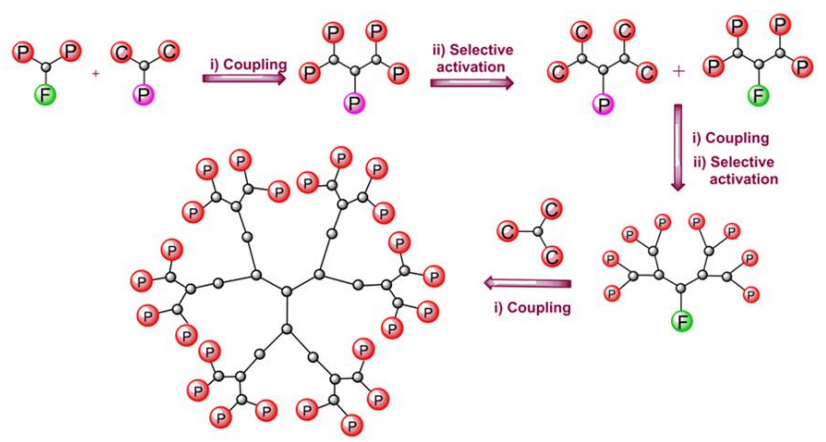

Fig. 6. Cartoon diagram is representingDouble-exponential convergent synthesis.

The functionalities at periphery and focal points should be arranged in such a manner that $\mathrm{AB}_{2}$ dendron couple to the site $\mathrm{C}$, and surface functionalities $\mathrm{B}$ should be neutral toward C. Similarly, when $\mathrm{CD}_{2}$ dendron couples to the site $\mathrm{B}$, surface functionalities $\mathrm{D}$ should be neutral toward B. Alternatively, $\mathrm{AB}_{2}$ and $\mathrm{CD}_{2}$ should be coupled to the desired core (Fig. 7). Thus activation and deactivation step are eliminated.
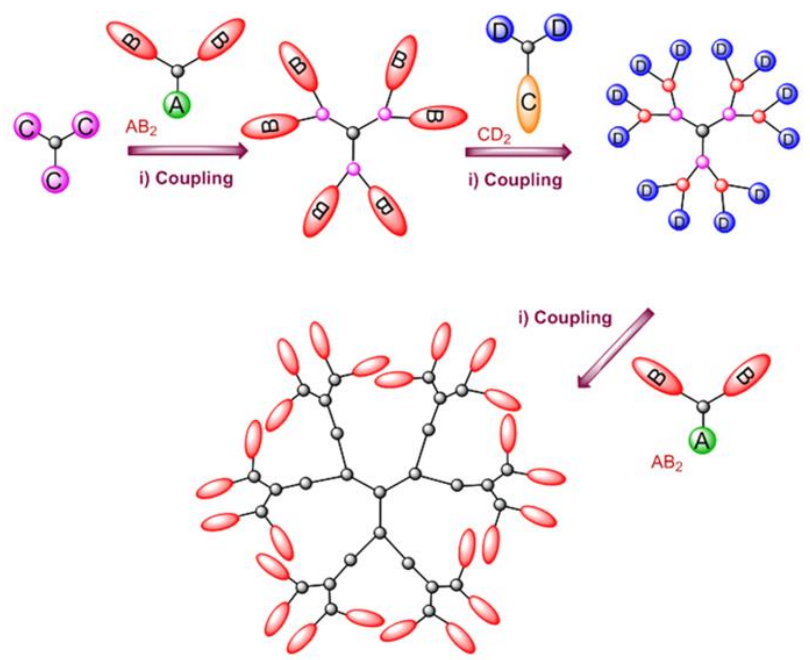

Fig. 7. Cartoon diagram is representing the orthogonal synthesis.

i. Chemoselective strategy: By orthogonal concept, Barany and Merrifield (in 1977) introduced the concept of chemoselectivity.This strategy has been utilized for peptide synthesis. The strategy was utilized for the construction of dendritic framework, which was first initiated by Spindler and Fréchet in 1993. Several numbers of dendrimers were constructed through chemoselective and orthogonal approaches by the discovery of click chemistry concept. The click concept was introduced in 2001 by K. B. Sharpless and co-workers. They found following observation by click chemistry concept.

- The products yields was very close to $100 \%$ and side products was null.

- The isolation of products was easy. 
Nowadays, copper-catalyzed Huisgen 1,3-dipolar cycloaddition (CuAAC) between azides and terminal acetylenes, is the most studied click reaction, which selectively forms the 1,4-substituted 1,2,3-triazole (Scheme 1). The exothermic CuAAC reaction displays a large thermodynamic driving force (i.e. $84 \mathrm{~kJ}^{-\mathrm{mol}^{-1}}$ ) to favor a single product.

In 2004, the CuAAC reaction was first reported as a chemical reaction for the conventional growth synthesis of triazole containing dendrimers [Meldal (2008)]. Presently, the click concept has proven to be a reliable synthetic platform to deliver complex macrostructures. The concept is today extended to include the Diels-Alder (DA) cycloaddition as well as the thiol-ene coupling (TEC), Scheme 1. In 2008, Hawker et al. illustrated the power of UV, initiated TEC for the divergent growth of generation four polythioether dendrimer. To date, a significant number of dendrimers has been constructed using click concept.

Copper catalysed Huisgen 1,3- dipolar cyclo- addition (CuAAC)

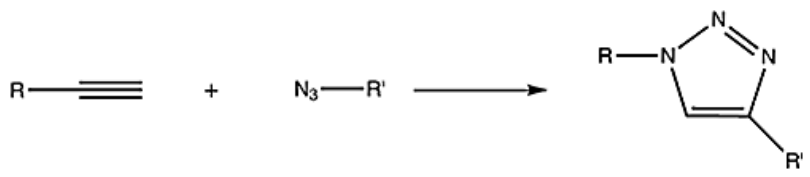

Diels Alder cycloaddition

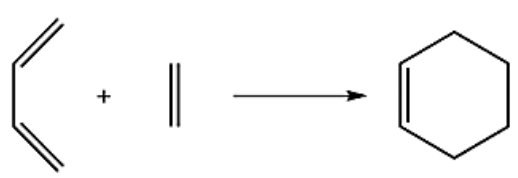

Thiol-ene coupling (TEC)

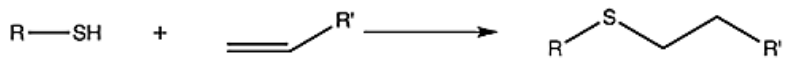

Scheme1. Schematic representation of common click reactions.

The orthogonal strategy now closely connected to the click reactions. This concept (click and the orthogonal strategy) was introduced by Malkoch [61] et al. in 2007, for the synthesis of four generation dendrimers, via one bis-MPA based and another Fréchet-type dendron [62]. Nowadays, several higher generation dendrimers are synthesized using orthogonal strategy and click coupling [63-67].

\section{One pot synthesis}

One-pot synthesis was initiated in the 1990's, but this attempt did not give fruitful result and dendrimers obtained were having high PDI i.e. up to 1.4. The first successful attempt regarding one pot system was made by Rannard and Davis et al. [68, 69]. They succeeded into synthesizing up to a third generation carbonate dendrimer. For simplicity, one-pot reactions were divided into two major parts, first the non-tandem reactions (NTRs) and the second one tandem reactions (TRs) [70]. NTRs take place consecutively, one at a time, while TRs take place independently of one another, and simultaneously also. Several dendrimers were also prepared using these approaches [71].

Besides the advantages of these reactions, it was still difficult to synthesize and isolate a perfect monodispersed dendrimer through one-pot reactions. Since formation of byproducts and uncontrolled perfect stoichiometry of the reagents made this method tedious, therefore these strategies are less utilized for the synthesis of monodisperse dendrimers.

3. Application: Among branched molecules, dendritic structures became the most innovative class of polymers and advancing entities [72]. Lot of dendrimers have been designed and synthesized on the basis of applications (biological to material applications). These includes liquid crystalline [73-75], chiral [76], miceller [77,78], amphiphilic [79-80], metalodendrimers $[\mathbf{8 1}]$, dendrimer nanorector $[\mathbf{8 2 , 8 3}$, dendrimernanoparticle $[\mathbf{8 4 , 8 6}], \quad$ dendrimer-based nanomedicine $[\mathbf{8 7 , 8 8}]$, drug delivery [89-91], gene delivery [92-94], light-harvesting [95,193], organoironmediated dendrimer syntheses [96], metallocene dendrimers as electrochrome molecular batteries [97,190], functionalized dendrimers [98], dynamers [99], catalysis $[\mathbf{1 0 0 , 1 0 1}$, dendrimers nanotube [102], nanocomposites [103], redox aspects $[\mathbf{1 0 4 , 1 0 5}]$ olefin metathesis [106], dendrimers in solution [107], photoactive dendrimers [108-110], multivalent neoglycoconjugates [111], biohybrid polymer capsules [112], cleavable dendrimers [113,114], dendritic nanomaterials [115], electrode design [116], solubility enhancers [117], gelators [118,119], light-emitting diodes [120-123], environmental remediation [124], MRI agents [125], biomimetics [126], folded dendrimers [127], nonlinear optics [128], quantum dots [129], molecular recognition [130], tailored dendrimers [131] and branched oligogermanes [132].

4. Different functionalities: On a molecular level the dendrimers are made up of small basic core units, branch, and periphery, which can incorporate several functionalities into these units. Thus a lot of dendrimers have been constructed incorporating different functionalities either at core, branches, terminal or mixture of any two and three of these dendritic units. These dendrimers are; heterocyclic dendrimers (triazine [133-134], porphyrin [135], thiophene [136,137], pyridines $\quad[\mathbf{1 3 8 , 1 3 9 ]}, \quad$ thiadiazole $\quad$ 140], carbazole[141,142], oxidazole $[143,144]$ benzothiozole [145], triazoles [146,147] etc), Heteroatoms containing dendrimers ( $\mathrm{Si}, \mathrm{P}, \mathrm{B}, \mathrm{Ge}$, or $\mathrm{Bi}$ ) [148], Different linkage (amide, anhydride, ester, ether, thioether, sulfonamide etc) containing dendrimers [149-155], homoaromatic, and polynuclear aromatic (nephthalene, anthracene, anullenes, etc.) [156-158] aliphatic dendrimers (only alkyl chain, hydroxyl, thiol and conjugated aliphatic chains) $[\mathbf{5 2 , 7 3}$ 75,159], dendrimers with biomacromolecules (glycodendrimers $[\mathbf{1 6 0}, \mathbf{1 6 1}]$, purins and pyrimidins [162,163] containing etc) and fullerene dendrimers [164].

Due to a large number of designs and synthetic approaches have been used to create these impressive 
structures. Thus a lot of dendrimers have been constructed, and literature is continuously growing, whose description is impossible through one review. Therefore, we shall mainly focus on the synthesis and applications of sulfone-based dendrimers. We will end with its importance in future developments.

The importance of sulfonel sulfonamide/sulfonimide based molecules

The development of sulfone-based dendrimers has been energized and elicited by the engrossing importance of sulfone functionality. Which are as following:

- Ease of synthesis of sulfone derivatives. Specialy, N,N-bis-sulfonylation reactions.

- These are the part of various biological systems [165168].

- The derivative of such molecules may behave like drugs (long range to small acting) [167-169], which shows antibacterial, antimicrobial, antidiabetic, antiretroviral, anticonvulsant, Cox-2 inhibitor and dermatologically based activities.[170]

- Sulfonyl acid chloride is the most active reagents for mono and bis functionalization of amines functionality among carboxylic acid chlorides or the corresponding active esters [171-174]. Sulfonyl acid chloride derivatives are also inexpensively available.

- In the biodegradable process, these linkages are easily cleavable [175].

Inspite of biological importance, nowadays, sulfone derivatives also played a major role in the material applications, i.e., sensing, electronic and nanotechnology to nanoscience [176-187].

\section{Need of sulfone-based dendrimers}

To keep dendrimers monodisperse and to avoid the formation of the side product, which are difficult to separate from the desired dendrimer. There were several methods of synthesis have developed and, continuously been progressing.

Nowadays, construction and functionalization of dendrimers have been successfully achieved through a wide variety of reactions, which are complete, fast, inexpensive and easy to handled. So, sulfone-based moieties come in that category, especially $\mathrm{N}, \mathrm{N}$ monosulfonylation and N,N-bissulfonylation based reactions fulfill all the criteria of novel dendrimer synthesis with high efficiency and less cost effectivity. However, the first iteration of N,N-bis-sulfonylation reaction on PAMAM dendrimers was initiated by Vögtle et al. [188,189].

Synthesis of sulphone/ sulfonimide/sulfonamide based dendrimers

Peripheral functionalization of dendrimers with the activated reagents was the most widely employed method to create dendrimers for possible application. Earlier, in this manner poly(propylenimine) dendrimers were selectively functionalized by carboxylic acid chlorides or the corresponding active esters as well as with the isocyanates and isothiocyanates [190-193]. However, these reactions were not generated complete functionalization. Fritz Vögtle et al. utilized sulfonic acid chlorides for mono and bifunctionalization of poly(propylenimine)-dendrimers. They started the $\mathrm{N}$ sulfonylation of poly(propylenimine)-dendrimers and proposed that the method can be utilized for the synthesis of higher generation sulfonimide based dendrimers [194196] as shown in Scheme 2.

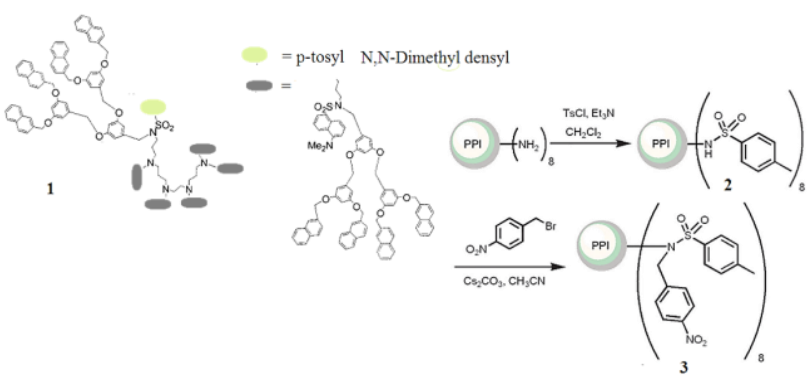

Scheme 2. Structural representation of N-sulfonamide based dendrimers.

Further, synthesis work of dendrimers, having sulfonimide units at the branching points, were also proceeded by Fritz Vogtle et al. in 2004 [197,198]. They gave a method for functionalization of oligoamines and tris(2-aminoethyl) amine via N,N-bis-sulfonylation with various arylsulfonyl chlorides derivatives and standardized reaction conditions utilizing different base. They reduced monosulfonylated precursor 4, using Ethanol $/ \mathrm{SnCl}_{2} / \mathrm{HCl}$ at $78{ }^{\circ} \mathrm{C}$, generated precursor 5 and applied it for the preparation of spherical dendrimers 6 , and 7 in $33 \%$ and $18 \%$ yield respectively in divergent fashion (shown in Scheme 3). Similarly, dumbell-shaped second-generation sulfonamide decorated dendrimer 8 was prepared.

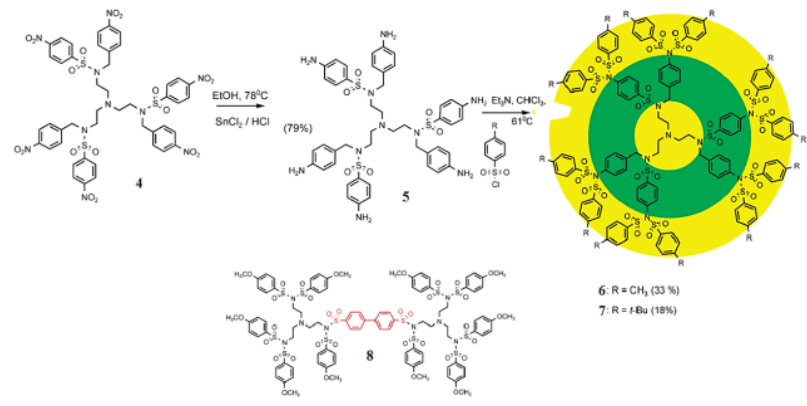

Scheme 3. Divergent synthesis of dendrimers possessing N-sulfonimide branching points.

Further, on the basis of mono- or bis-sulfonylation, Oleg Lukin et al. constructed several higher generation dendrons and Janus-type dendrimers (up to the third generation) possessing sulfonimide units at every branching point by convergent pathway [199], described in Scheme 4a and $\mathbf{4 b}$. Synthetic steps involved, $\mathrm{N}$-sulfonylation, persulfonylation of amines, reductions of nitroaromatic compounds, and the Suzuki cross coupling (SCC), in which n-octylamine was persulfonylated by p-nitro sulfonyl chloride gave 9 in 
$95 \%$, which on reduction using $\mathrm{HCl} / \mathrm{EtOH} / \mathrm{SnCl}_{2}$ at reflux, led to the formation of generation one (G1) dendron 10. Further, these steps were repeated and led to the formation of higher generation dendrons $\mathbf{1 1}$ and $\mathbf{1 3}$ in $71 \%$ and $57 \%$ respectively. Similarly, dendrons $\mathbf{1 4 - 2 1}$ were synthesized in decreasing yield as crowding increased (Scheme 4a). Further utilization of Suzuki cross-coupling (SCC), dendrimers 22,23 and 24 were prepared by the coupling of dendrons $\mathbf{1 7 , 1 9}$ and $\mathbf{2 1}$ to the core 1,4-phenylene diboronic acid diester, in presence of $\mathrm{Pd}\left[\left(\mathrm{P}(p-\mathrm{Tol})_{3}\right]_{3}, \mathrm{THF} / \mathrm{H}_{2} \mathrm{O}\right.$ at $80{ }^{\circ} \mathrm{C}$ for $24 \mathrm{~h}($ Scheme $4 \mathbf{b})$.

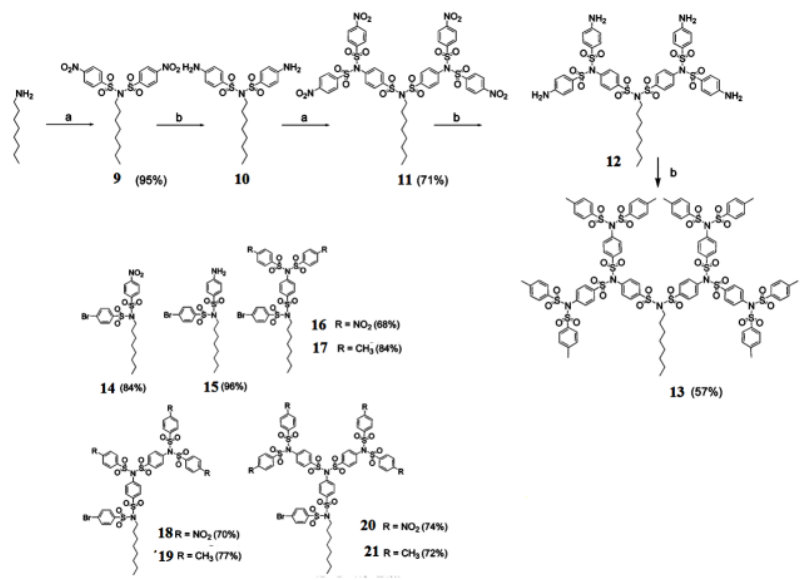

Scheme 4a: Synthesis of dendrons and reagent condition (a) $\mathrm{ArSO}_{2} \mathrm{Cl}$, $\mathrm{Et}_{3} \mathrm{~N}, \mathrm{CH}_{2} \mathrm{Cl}_{2}$, reflux; (b) $\mathrm{SnCl}_{2}, \mathrm{HCl}, \mathrm{EtOH} / \mathrm{DCM}$, at $40{ }^{\circ} \mathrm{C}$.

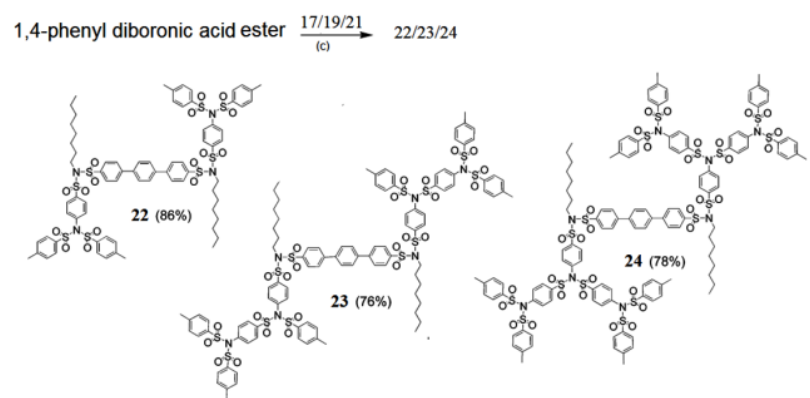

Scheme 4b: Synthesis of dendrimers 22, 23 and 24 reagent condition (c) $\mathrm{Pd}\left[\left(\mathrm{P}(p \mathrm{Tol})_{3}\right]_{3}, \mathrm{THF} / \mathrm{H}_{2} \mathrm{O}, 80{ }^{\circ} \mathrm{C}, 24 \mathrm{~h}\right.$.

They concluded that -

- Dendrons possessing $-\mathrm{NO}_{2}$ functionalities $(\mathbf{1 6}, 18$ and 20) was unable to couple through SCC

- Reduction condition (absolute ethanol and $\mathrm{Sn}$ granule) causes cleavage of one of the sulfone linkage.

- Catalytic hydrogenation causes dehydrohalogenation in dendrons having bromoaromatic functionalities.

Further in 2007, Oleg Lukin et al. overcome the previous problems (reduction condition) [200]. In previous reduction condition, the catalytic hydrogenation caused partial dehydrohalogenation in dendrons having bromoaromatic functionalities (14-17). The reduction in refluxing ethanol using $\mathrm{SnCl}_{2}$ led to the splitproduct $\mathbf{2 8}$ through short-lived species 27 (see Scheme 5a). On modification of the previous reduction procedure they utilized 1:1 mixture of ethanol/dichloromethane at $40{ }^{\circ} \mathrm{C}$ for $20-40 \mathrm{~min}$, in place of absolute ethanol at $78^{\circ} \mathrm{C}$, led to the formation of amine 26 in quantitative yield (100\%). Further, combining the new reduction procedure and previously reported monosulfonylation and persulfonylation, several higher generations dendrons were prepared as shown in Scheme 5a, In which dendrons 31d was doubly coupled through core 1,4phenylenediboronic acid via SCC gave the pentaphenylene centered dendrimer $\mathbf{3 2}$ in yield $70 \%$ (see Scheme 5b).

D. Schubert and Oleg Lukins's group reported a topological study of the above described dendrons and dendrimers [201]. The photophysical study of dendrimer 32 was also started by Vögtle et al. [202] and developed by G. Bergamini et al., who gave the photophysical properties (absorption, emission, and excitation spectra; fluorescence decay lifetime and fluorescence anisotropy spectra), using different experimental conditions i.e. dichloromethane solution and solid state at $293 \mathrm{~K}$, dichloromethane/methanol rigid matrix at $77 \mathrm{~K}$ [203206].

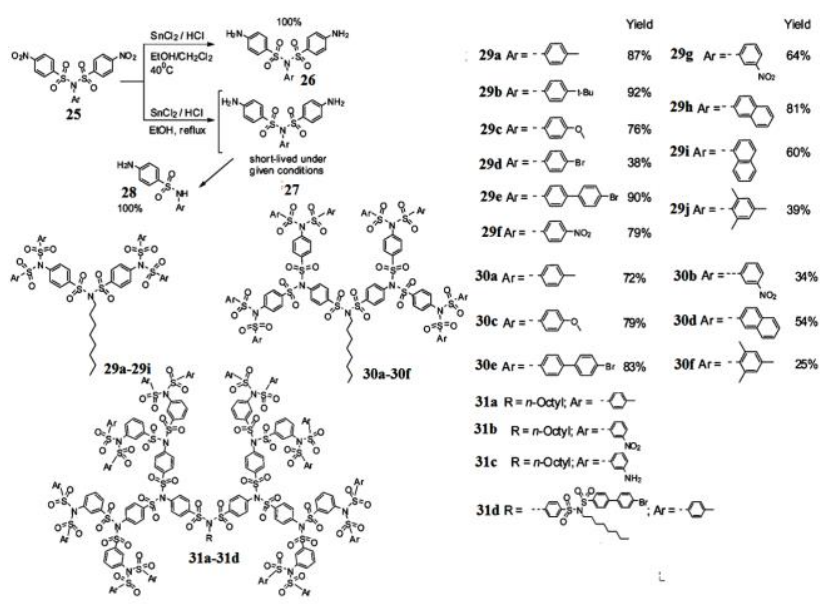

Scheme 5a: structural representation of new reduction method and dendrons series.

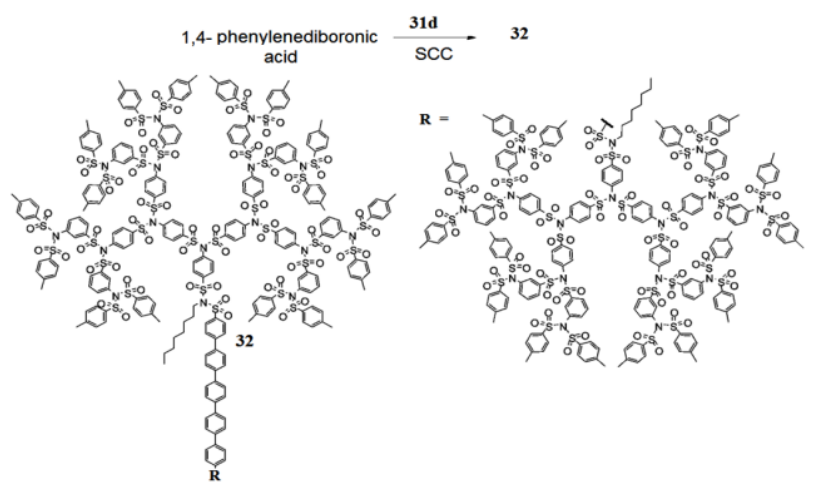

Scheme 5b: Synthesis of dendrimers 32. Reagent condition of SCC $\left\{\mathrm{Pd}\left[(\mathrm{P}(p-\mathrm{Tol}) 3] 3, \mathrm{THF} / \mathrm{H}_{2} \mathrm{O}, 80^{\circ} \mathrm{C}, 24 \mathrm{~h}\right\}\right.$.

Moreover, Paul C. Taylor developed a divergent route for G1 oligo(aryl sulfone)s and a G2 oligo(aryl sulfone) dendrimer [207, 208], using nucleophilic aromatic substitution reactions, described in Scheme 6 In this interesting synthesis, they have used compound $\mathbf{3 3}$ and trichlorobenzene as starting material and coupled them to prepare 34 which on oxidation of central sulfur gave $\mathbf{3 5}$. 
Further, repetition of steps coupling and oxidation, several other intermediate 36, 37, 38, and 40 were constructed. Only 38d and 40d were utilized for the construction of dendrimers $\mathbf{3 9}$ and $\mathbf{4 1}$ in $\mathbf{7 4 \%}$ and $80 \%$ yield, respectively.

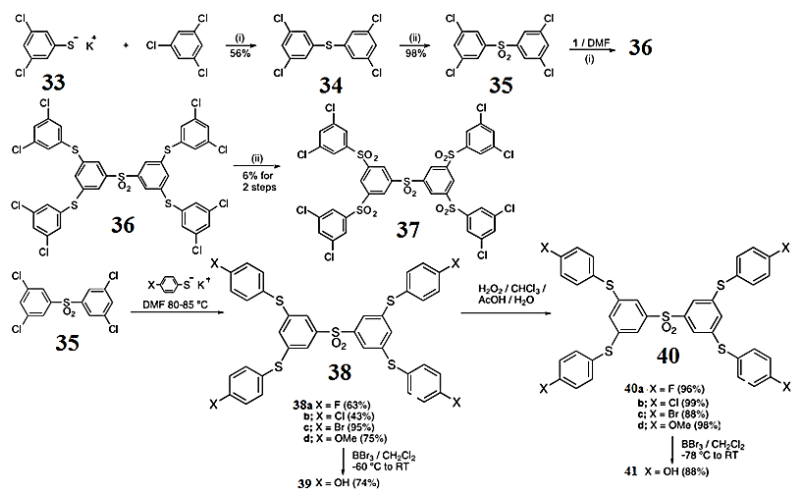

Scheme 6. The divergent construction of sulfone-based dendrimers.

In another way of elegant synthesis Scheme, 7 Matsumura et al. synthesized novel hexakis(4-(4fluorophenylsulfonyl)phenyl)benzene $\mathbf{4 3}$ in $60 \%$ via Friedel Craft reaction. The reaction of hexaphenylbenzene 42 with 4-fluorobenzenesulfonyl chloride in the presence of iron(III) chloride. They utilized this small generation dendrimer for theconstruction of multiblock copolymers [209].
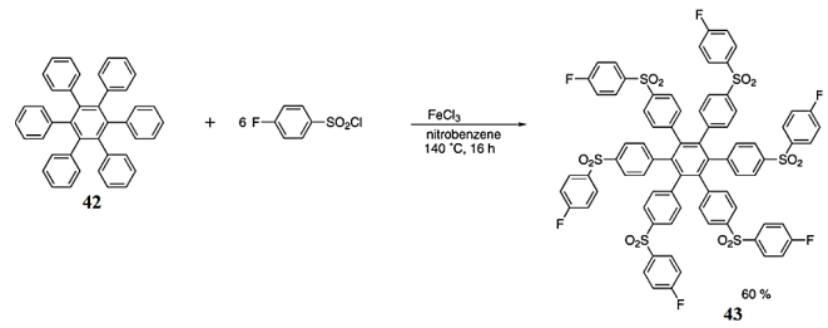

Scheme 7. A simple route to sulfone-based dendrimers via FC reaction.

In very recently Tewari et al. constructed several triazine cored sulfonimide dendrimers 44a-44 d (triarmed) and 45a-45d (hexa-armed) via click reaction (see Scheme 8) [210]. They gave an efficient method of click synthesis and obtained both $\mathrm{Cu}$-free and $\mathrm{Cu}$ complexed dendrimers in good yield.

Application: Above section described, sulfone/sulphonamide and sulfonimide based, dendrimer synthesis. Nowadays, several sulfone-based dendrimers were synthesized for their important applications. Therefore, in this part, we shall describe synthesis and application of sulfone-based dendrimers

Biological application: In the following examples, we shall illustrate work of Paula Ortega et al.. They utilized the sulfone-based dendrimers (carbosilane dendrimers containing dansyl groups at their periphery as shown in Scheme 9) as biologically active tools [211]. Paula Ortega et al. developed their previous synthesis of carbosilane dendrimers [212-219], to prove the internalization studies of carbosilane dendrimers. They carried monosulfonylation, at the periphery of previous dendrimers, by dansylchromophoric group (i.e. 5-(dimethylamino)-1-naphthalenesulfonamido) and prepared dendrimers 46a-46c. Further, these dendritic systems were tested for in vitro toxicity on primary cell cultures (dendritic and peripheral blood mononuclear cells), and their cellular uptake was studied using confocal fluorescence microscopy.

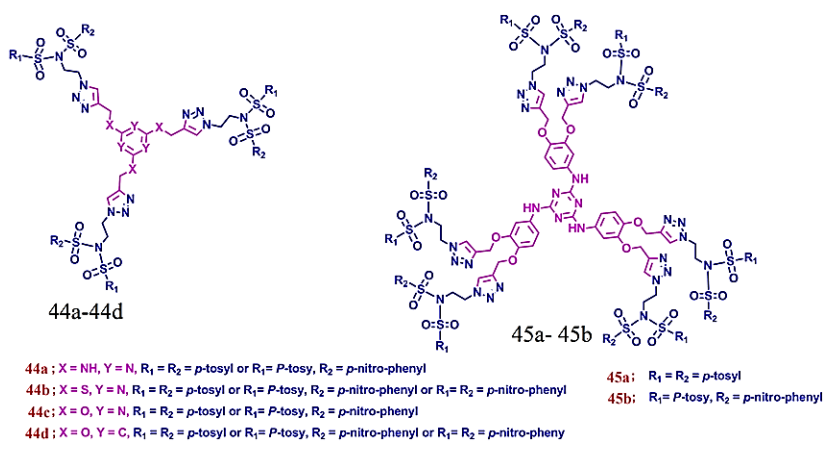

Scheme 8.Triazine cored sulfonimide dendrimers 44a-44d (tri-armed) and 45a-45b (hexa-armed).

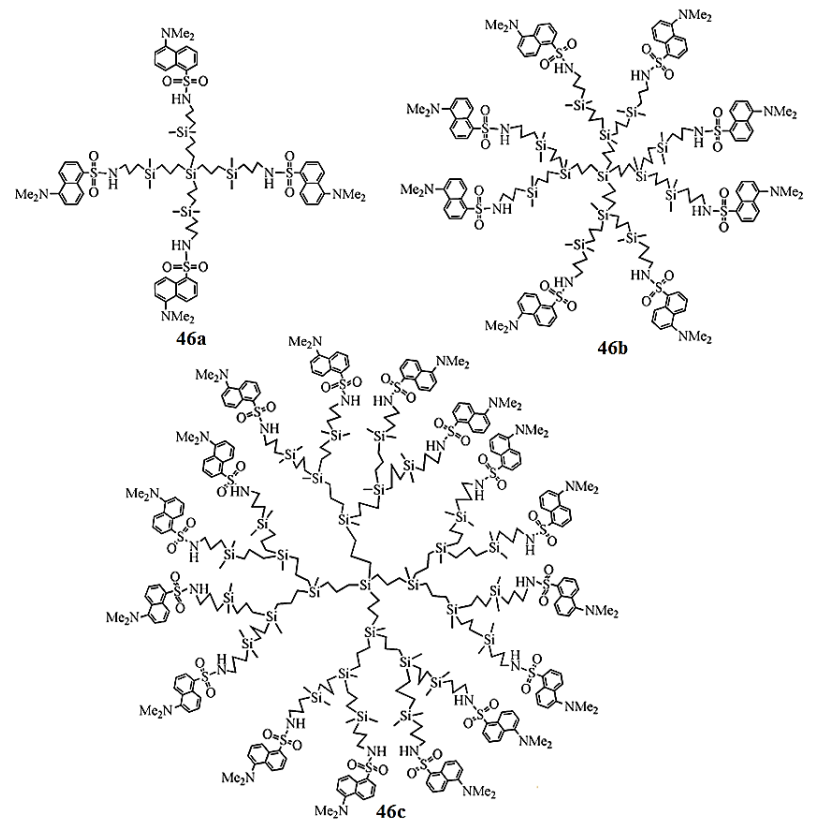

Scheme 9.Structural representation of per-dansylated dendrimers 46a46c.

On the other hand, J. M. Sanfrutos utilized PAMAM dendrimers to functionalized their primary amino groups to vinylsulfone group via aza-Michael type addition reaction and prepared upto two generation dendrimer series bearing peripheral alkyl sulfonyl hydrophobic tails $\mathbf{( 5 2 - 5 4 )}$ as shown in Scheme $\mathbf{1 0}[\mathbf{2 2 0}]$. For this they prepared vinylsulfone series $47,48,49$, and 50 , which were subsequently treated with the PAMAM amine group in the presence of 1:1 mixture of THF/Water at r.t., gave G1 dendrimers 51a-d. Similarly, G-2 series 52-55 were prepared. These dendrimers were utilized for gene delivery. For this, they compare the transfection properties of native PAMAM-G2 dendriplexes and amphiphilic sulfone-based dendrimer. They found, 
dendrimers (52-55) were highly efficient for gene delivery. The incorporation of hydrophobic alkyl chains of different length was anticipated to be a structural factor that would positively contribute to improving the cellular uptake and internalization of the corresponding dendriplexes synergistically. A. M. Fernandez et al. created an exciting vinyl sulfone ferrocenylation reagents [182]. The key sequence of reaction is shown in Scheme 11, In which compounds $\mathbf{5 8 a}$ and $\mathbf{5 8 b}$ were simultaneously coupled to tris (2-aminoethyl) amine (6) through Michael-type addition and created G1 dendrimers 56, 57 and 58. Azide derivative $\mathbf{6 0}$ was synthesized in two steps $\mathbf{i}$ and ii via precursors $\mathbf{5 8}$ and 59. Similarly, recombination of the monomers 58a and $\mathbf{5 8 b}$ to the aminosugars, cyclodextrins, tripeptide glutathione (GSH), glutathione disulfide (GSSG) created conjugates and bioconjugates (ferrocenyl terminated dendrimers $\mathbf{5 7}$ and ferrocene-sugar 61, ferrocene-peptide, ferrocene protein conjugates 62 and 63, ferrocene-cyclodextrin 64 and 65 ,). These biomolecules were found for strong bioactivity.

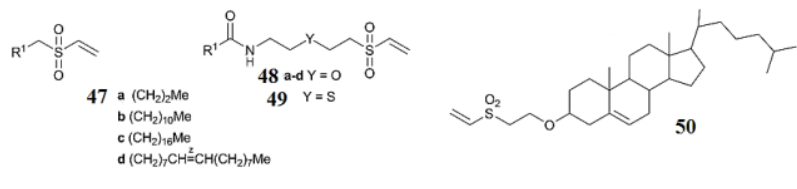

Aza-Michael addition:
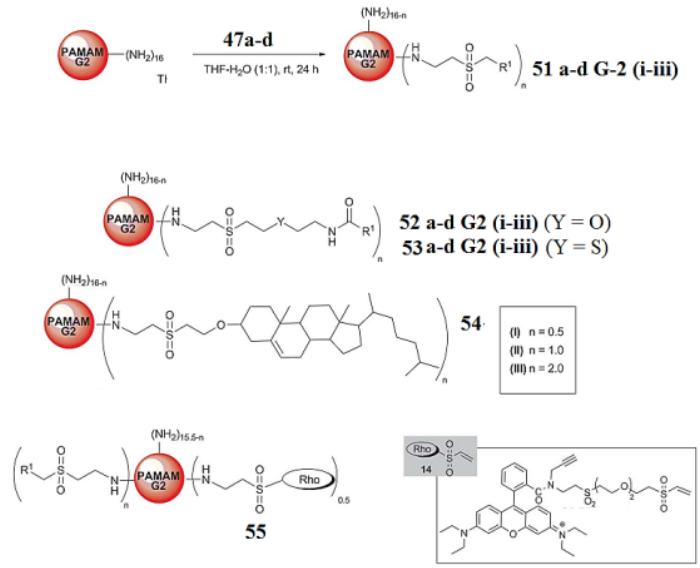

Scheme 10. Surface coupling of PAMAM dendrimers via Aza-Michael addition to prepared dendrimers having sulfone units at terminal branches.

In very recent Fabrizio Carta and coworkers also used poly(amidoamine) (PAMAM) dendrimers and their amines were surface functionalized with benzene sulfonyl chloride and created an innovative series of sulfonamide terminated dendrimers 66G0, 66G1, 66G2 and 66G3 [222] (see Scheme 12). Further, developing their Work, they utilized dendrimers (66G0-66G3) for medicinal chemistry applications and investigated benzenesulfonamide moieties of these dendrimers shows strongly human carbonic anhydrase inhibiting properties. Inhibiting properties increases as the sulfonamide molecules increases on going from G0-G3.

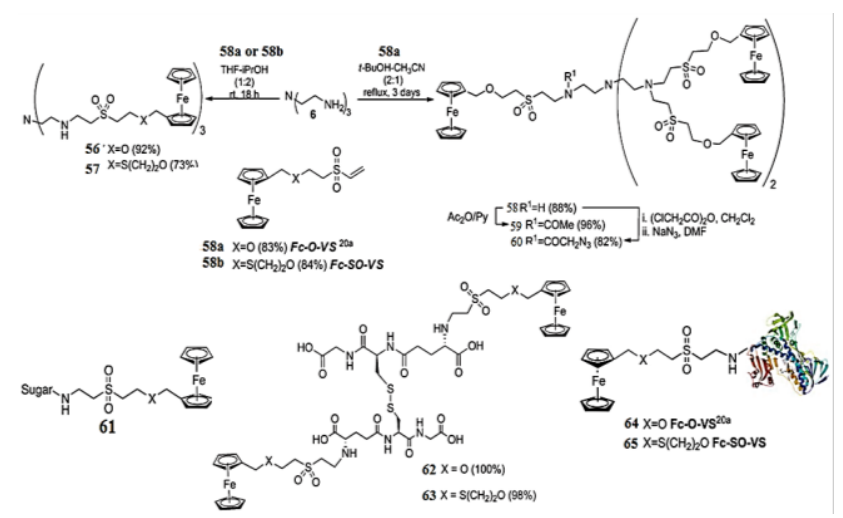

Scheme 11: Synthesis of bioactive dendrimers possessing sulfone units.
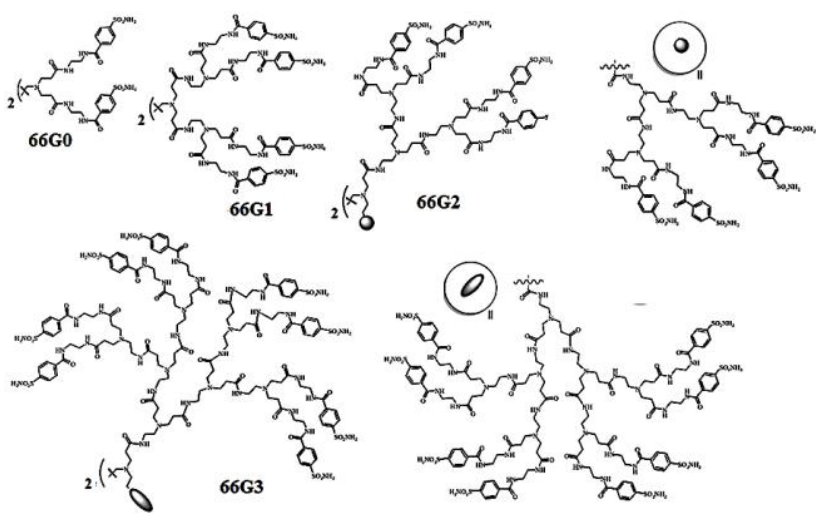

Scheme 12: Structure of sulfonamide terminated dendrimers G0-G3.

Material application: Sulfone based dendrimers constitute one of the most important research topics. Inspite of biological applications, some of the sulfonebased dendrimers were constructed, which shows significant interest in materials applications. Now, we shall explore several sulfone-based dendrimers possessing excellent liquid crystalline, non-linear optical and fuel cell properties.

Liquid crystalline [LC]: Dendrimers and Dendrons proved particularly versatile candidates for the elaboration of new LC materials [222]. Particularly, the dendritic structure is an interesting framework, where liquid crystalline behavior can be modulated by very subtle modifications of the dendritic connectivity. There have been several kinds of dendrimers constructed such as side-chain liquidcrystalline dendrimers, silicon-containing LC dendrimers, polyamide amine (PAMAM), polypropyleneimine (PPI) dendrimers, Polyester, polyether LC dendrimers, ferrocene and/or C-60 subunits containing LC dendrimers. Recently, M. M. Manas and co-workers reported the synthesis of the 15 membered triolefinic aza-macrocycles functionalized with appropriate are sulfonamide groups as well as their palladium(0) complexes 67, 68 and 69 has been explored in Scheme 13 [223]. 


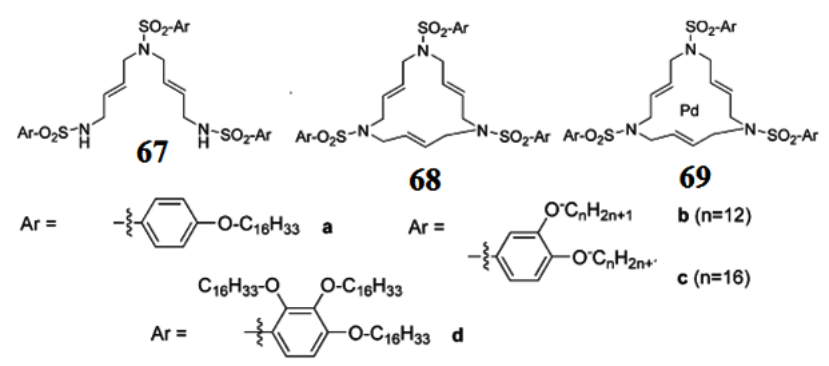

Scheme 13.Synthesis of Liquid crystalline dendrimers bearing Nsulfonamide moieties.

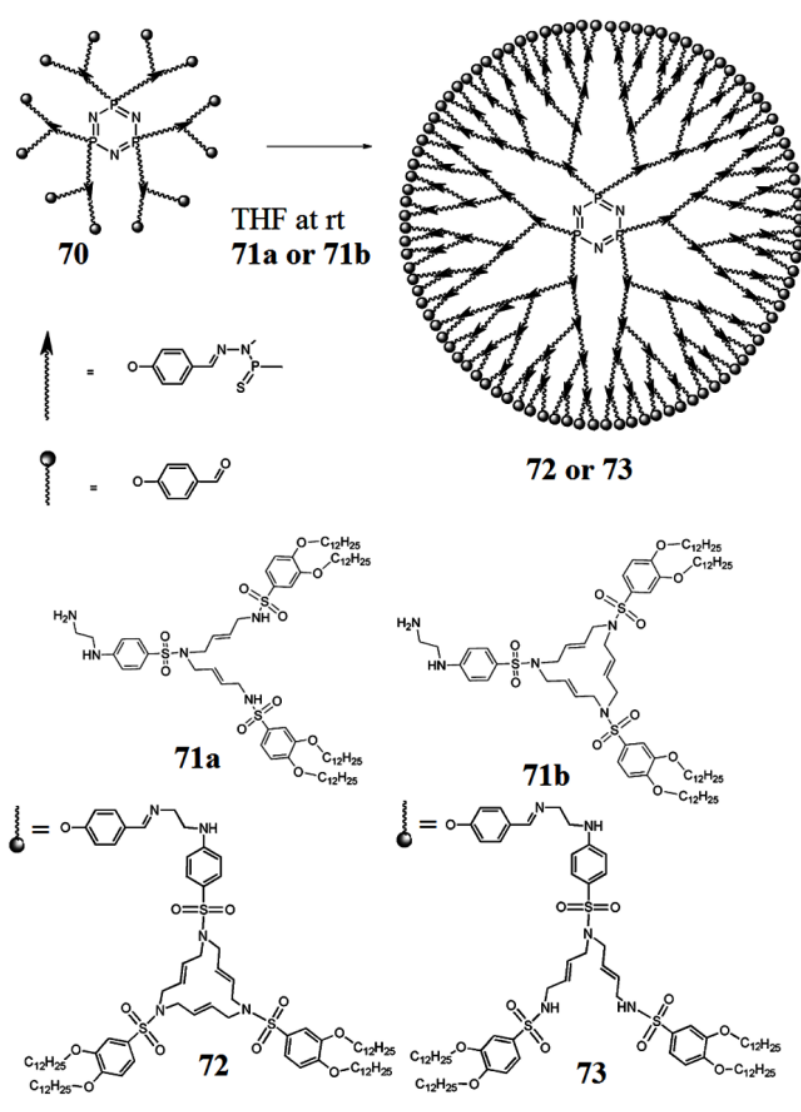

Scheme 14.Synthesis of $\mathrm{N}$-sulfonamide dendrimers with mesogenic properties.

The mesomorphic behavior of the compounds was studied by polarizing optical microscopy, differential scanning calorimetry and X-ray diffraction, which enabled the determination of the structural parameters.

Very recently, C. A. Hincapi et al., by their previous work based on small liquid crystalline molecules, prepared a series of liquid crystalline dendrimers. They constructed liquid crystalline dendrimers by combining phosphorus dendrimers with sulfonamide derivatives. Thus generated dendromesogens $\mathbf{7 2}$ and $\mathbf{7 3}$ bearing mesogenic units on their surfaces (see Scheme 14) [224]. These effects are probably due to the establishment of inter- and intra-molecular hydrogen bonds, generated by the external sulfonamide moieties bearing N-H bonds.

$\mathrm{W}$. Wu and Zen Li's group reported two series of sulfonyl based high-generation NLO dendrimer 79 through the combination of the divergent, convergent approaches, and Sharpless click reaction, Which was easily constructed with high purity and satisfactory yields. Although they previously prepared several nitro groups containing dendrimers, that dendrimers demonstrated high $\left(d_{33}\right)$ second harmonic generation coefficient values (NLO coefficient). In the present work, they found sulfonylbased chromophore dendrimers have high optical transparency and NLO stability comparatively without sulfone units. Basic outlook of the synthesis was explained in Scheme 15. In which intermediate 76 was clicked to the $\mathbf{7 4}$, led to the formation of $\mathbf{7 7}$, which on diazotization using 75, gave 78. Repeating these steps dendritic series have been constructed [225, 226].

Kunpeng Li [227] et al. gave an easy convergent synthetic strategy of dendrimer synthesis without protection/deprotection steps. Synthetic steps were a combination of several reactions like Friedel Craft acylation, Vilsmeier reaction, Heck coupling in dendrons and Wittig-Horner reaction, summarized in Scheme 16. Donor core 82 and acceptor dendrons d0, d1, and d2 were synthesized by applying these reactions, where sulfonylation of toluene gave $\mathbf{8 0}$, which on bromination and phosphorylation led to the formation of $\mathbf{8 1}$ and core 82. Further dendron do was synthesized via Vilsmeier reaction, which acts as a precursor for 83 and $\mathbf{8 4}$. Heck coupling between $\mathbf{8 3}$ and $\mathbf{8 4}$ in the presence of $\mathrm{Pd}(\mathrm{oAc})_{2} / \mathrm{K}_{3} \mathrm{PO}_{4}$, gave dendron d1. Similarly, d2 was synthesized. Further, dendrons d0-d2 were coupled through Wittig-Horner reaction to the core 82, led to the formation of novel dendrimers generations (G0-G2) $\mathbf{8 5}$, 86 and 88. These dendrimers were applied for hetero junction solar cells, in which dendrimer G0 shows a relatively high power conversion efficiency (PCE) of $0.34 \%$ under AM 1.5 illumination of $100 \mathrm{mWcm}^{2}$.

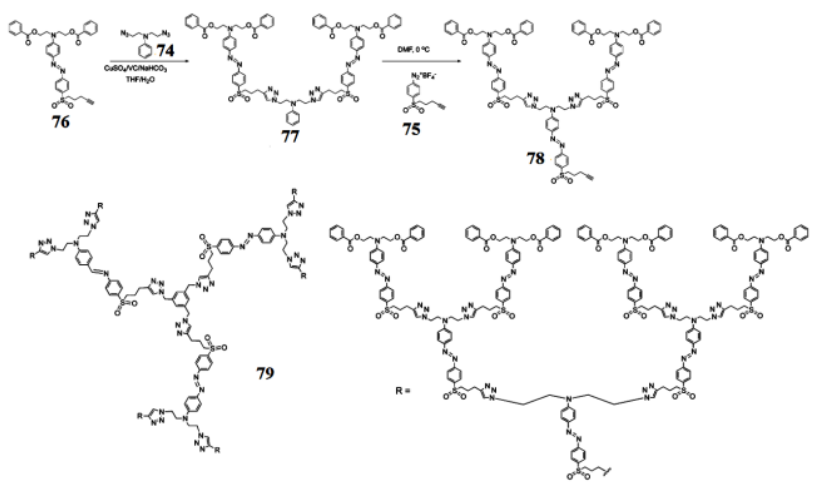

Scheme 15.Convergent synthesis of dendrimers via CuAAC having NLO properties.

In Scheme 17, the sulfone core was again utilized by P. Rajakumar et al.. They developed their previous work of benzothiazole terminated dendrimers [228], utilizing the click coupling to construct the dendrimers $\mathbf{8 8}, \mathbf{8 9}$ and 90. They used, these dendrimers in dye-sensitized solar cells (DSSC) as additives, which exhibited good current generating capacity and a power conversion efficiency in higher-generation than lower generation dendrimers. 

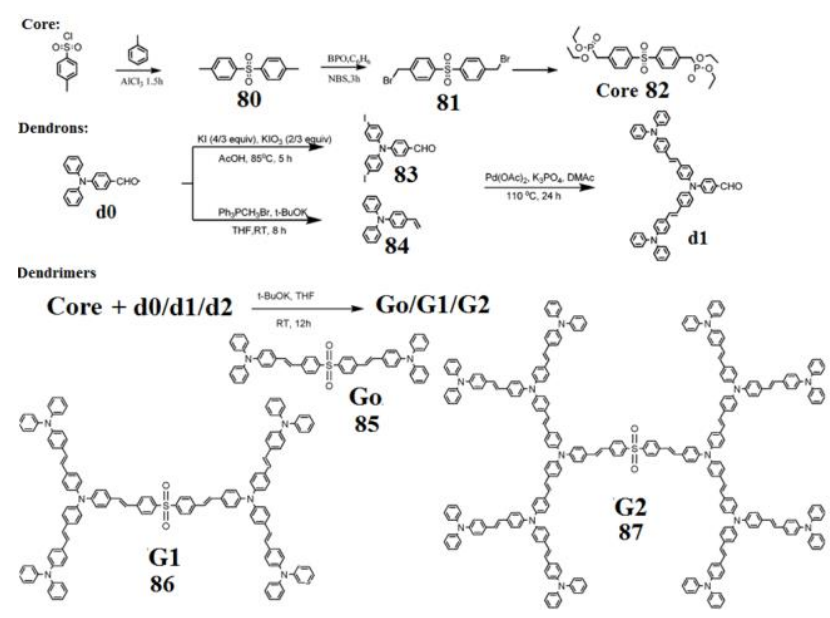

Scheme 16. The simple synthesis of sulfone cored dendrimers.

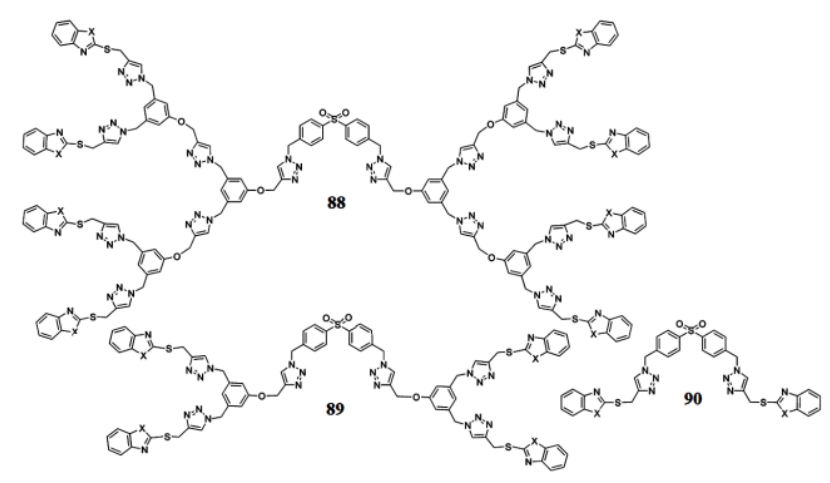

Scheme 17.The sulfone cored dendrimers are bearing good DSSC properties.

Recently, M. M. Zerco et al. gave a straightforward procedure for the synthesis of a novel sulfonated dendrimers 93 and 94 with a PES backbone [229]. Dendrimer 94 was blended with poly-[1-(4, 4-diphenylether)-5-oxybenzimidazole]benzimidazole (PBIOOVR) at different ratios to prepare a series of acidbase PEMs (Scheme 18). They studied these dendrimers as a fuel cell.

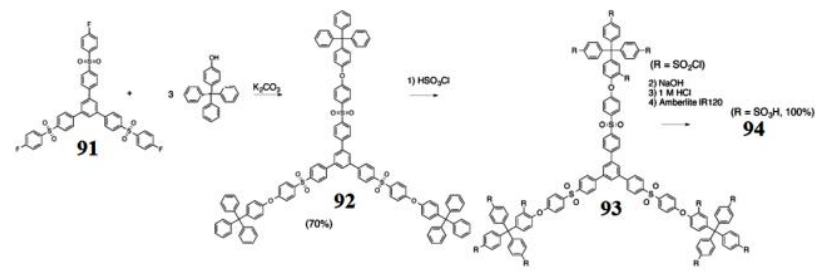

Scheme 18. Synthesis of the polysulfonated dendrimer 93 and 94 with a PES backbone.

\section{Future viewpoint}

An analysis of the sulfone/sulphonamide/sulfonimide chemical structures, synthesis methods and applications presently available reveals that these dendrimers have not been fully explored yet. Both synthetic and application aspects can be enhanced by introducing heterocyclic, polycyclic hydrocarbon heteroatoms, etc. triazine with sulfone/ sulfonamide or sulfonimide. As a final remark, combined with advancing functionalities these dendrimers will have a great impact on dendrimer synthesis. It would advance the application of such dendrimers.

\section{Conclusion}

In this article, we deliberated to review the comprehensive description of sulfone-based dendrimers synthesis and their biological to material applications. We have described the type of dendrimers, importance, and need of sulfone derivatives and the chemistry, in short. It was observed that till now several kinds of sulfone-based dendrimers were constructed by utilizing different reactions, but $\mathrm{N}, \mathrm{N}$-bis-sulfonylation reaction were fast and complete. Thus several dendritic assemblies were also created that possessing sulfonamide units and have applications. This article is endeavoring to find potential future directions in the development of more analogs of sulfone-based dendrimers synthesis for various biological to material applications. We expected that the information given in this article will not only modernize the researchers with recent synthesis and applications of these dendrimers but also buoy up them to use this promising moiety for the design of new molecules with enriched medicinal and material properties, that are leading to novel treatments luxury agents for the benefit of humanity and technology.

\section{Acknowledgements}

SK, SKR and AKT thanks to Department of Chemistry, Institute of Science of Banaras Hindu University for the facilities.

\section{References}

1. Jana, A.; Paikar, A.; Bera, S.; Maity, S.; Haldar, D.Org. Lett. 2013, $16,38-41$.

DOI: $10.1021 / 01402865 t$

2. Singh, S.; Aggarwal, A.; Bhupathiraju, N. V. S. D. K.; Arianna, G.; Tiwari, K.; Drain, C. M.Chem. Rev. 2015, 115, 10261-10306. DOI: $10.1021 /$ acs.chemrev.5b00244

3. Binnemans,K. Chem. Rev. 2009, 109, 4283-4374. DOI: $10.1021 / \mathrm{cr} 8003983$

4. Singla, P.; Luxami, V.; Paul, K. E. J. Med. Chem.2015, 102, 39-57.DOI: $10.1016 /$ j.ejmech

5. Aaron, J. L.; Villaraza, A. B.; Martin, W. B. Chem. Rev. 2010, 110, 2921-2959.

DOI: $10.1021 /$ cr900232t

6. Hoeben, F. J. M.; Jonkheijm, P.; Meijer, E. W.; Schenning, A. P. H. J. Chem. Rev. 2005, 105, 1491-1546. DOI: $10.1021 / \mathrm{cr} 030070 \mathrm{z}$

7. Vriezema, D. M.; Aragonés, M. C.; Elemans, J. A. A. W.; Cornelissen, J. J. L. M.; Rowan, A. E.; Nolte, R. J. M. Chem. Rev. 2005, 105, 1445-1490. DOI: $10.1021 / \mathrm{cr} 0300688$

8. Caminade, A. M.; Ouali, A; Laurent, R.; Turrin, C. O.; Majoral, J. P.Coord.Chem. Rev.2016, 308, 478-497. DOI: $10.1016 /$ j.ccr.2015.06.007

9. Grimsdale, A. C., Chan, K. L.; Martin, R. E.; Jokisz, P. G.;Holmes, A. B. Chem. Rev. 2009, 109, 897-1091. DOI: $10.1021 / \mathrm{cr} 000013 \mathrm{v}$

10. Grayson, S. M.; Fréchet, J. M. J. Chem. Rev. 2001, 101, 3819-3868.

DOI: $10.1021 / \mathrm{cr} 990116 \mathrm{~h}$

11. Fujita, K.; Hattori, H. Tetrahedron.2016, 64, 1485-1492. DOI: $10.1016 /$ j.tet.2016.01.048

12. Yao, Q.; Kinney, E. P.; Yang, Z. J. Org. Chem. 2003, 68, 7528-7531.

DOI: $10.1021 /$ jo034646w 
13. Günay, K. A.; Theato, P.; Klok, H. A. J. Polym. Sci. Part A: Polym. Chem.2013, 51, 1-28.

DOI: $10.1002 /$ pola. 26333

14. Tanaka, T.; Arimoto, R.; Sakai, S.; Fujii, M.; Yamamoto, M. K. J. Am. Chem. Soc. 2005, 127, 13896-13905.

DOI: $10.1021 / \mathrm{ja} 0524797$

15. Suzuki, M.; Nakajima, R.; Tsuruta, M.; Higuchi, M.; Einaga, Y.; Yamamoto, K.Macromolecules. 2006, 39, 64-69. DOI: $10.1021 / \mathrm{ma} 052268 \mathrm{~m}$

16. Chinchilla, R.; Nájera, C. Chem. Rev. 2007,107, 874-922. DOI: $10.1039 / \mathrm{C} 4 \mathrm{RA} 09105 \mathrm{~A}$

17. Karak, M.; Barbosa, L. C. A.; Hargaden, G. C. RSC. Adv. 2014, 4, 53442-53466.

DOI: $10.1039 / \mathrm{C} 4 \mathrm{RA} 09105 \mathrm{~A}$

18. Meldal, M.; Tornøe, C. W. Chem. Rev. 2008,108, 2952-3015. DOI: $10.1021 / \mathrm{cr} 0783479$

19. Thirumurugan, P.; Matosiuk, D.; Jozwiak, K.Chem. Rev. 2013, 113, 4905-5028.DOI: $10.1021 / \mathrm{cr} 3003888$

20. Kose, M. M.; Gulen, Y. S. A. Org. Lett. 2008, 10, 2353-2356. DOI: $10.1021 / \mathrm{ol} 800553 \mathrm{t}$

21. Tong, R.; Tang, M. L. L.; Tu, C.; Baumgartnerb, R. C. Chem. Soc. Rev. 2014, 43, 6982-7012.

DOI: $10.1039 / \mathrm{c} 4 \mathrm{cs} 00133 \mathrm{~h}$

22. Zheng, Y.; Li, S.; Wenga, Z.; Gao, Chao; Chem. Soc. Rev. 2015, 44, 4091-4130. DOI: $10.1039 / \mathrm{c} 4 \mathrm{cs} 00528 \mathrm{~g}$.

23. Raffa, P.; Zakarias, D. A.; Picchioni, W. F. Broekhuis, A. A. Chem. Rev. 2015, 115, 8504-8563.

DOI: $10.1021 / \mathrm{cr} 500129 \mathrm{~h}$.

24. Bosman, A. W.; Janssen, H. M.; Meijer. E. W. Chem. Rev. 1999 99, 1665-1688. DOI: $10.1021 / \mathrm{cr} 970069 \mathrm{y}$

25. Flory, P. J. J. Am. Chem. Soc. 1941, 63, 3096-3100. DOI: $10.1021 / \mathrm{ja} 01856 \mathrm{a} 063$.

26. Flory, P. J. J. Am. Chem. Soc.1952, 74, 2718-2723. DOI: $10.1021 / \mathrm{ja} 01131 \mathrm{a} 008$

27. Vögtle, F.; Buhleier, E. W.; Wehner, W. Synthesis.1978, 2, 155-158.

DOI: $10.1055 / \mathrm{s}-1978-24702$.

28. Denkewalter, R. G.; Kolc, J. F.; Lukasavage, W. J. Macromolecular Highly Branched Homogeneous Compound. U.S. Pat. 1983, 4, 410, 688.

29. Tomalia, D. A. Prog. Polym. Sci. 2005, 30, 294-324.

DOI:10.1016/j.progpolymsci.2005.01.007

30. Newkome, G. R.; Yao, Z.; Baker, G. R.; Gupta, V. K. J. Org. Chem. 1985, 50, 2003-2004.

DOI: $10.1021 /$ jo00211a052

31. Newkome, G. R.; Baker, G. R.; Young, J. K.; Traynham, J. G. J. Polym. Sci., Part A: Polym. Chem., 1993, 31, 641-651

DOI: $10.1002 /$ pola.1993.080310307.

32. Brabander-van den, B. E. M. M., Meijer, E.W. Angew Chem. Int. Ed. Engl.1993, 32, 1308-1311.

33. Hawker, C. J.; Fréchet, J. M. J. J. Am. Chem. Soc. 1990, 112, 7638-7647. DOI: $10.1021 / \mathrm{ja} 00177 \mathrm{a} 027$

34. L'abbe, G.; Forier, B.; Dehaen, W. Chem. Commun. 1996, 115, 2143-2144.

DOI: $10.1039 / \mathrm{CC} 9960002143$

35. Moore, J. S. Acc. Chem. Res. 1997, 30, 402-413. DOI: $10.1021 / \operatorname{ar} 950232 \mathrm{~g}$

36. Zeng, F.; Zimmerman, S. C. Chem. Rev. 1997, 97, 1681-1712. DOI: $10.1021 / \mathrm{cr} 9603892$

37. Jarayaman, N.; Negopodiev, S. A.; Stoddart, J. F. Chem. Eur. J. 1997, 3, 1193-1199.

DOI: $10.1002 /$ chem.19970030804

38. Newkome, G. R.; He, E.; Moorefield, C. N. Chem. Rev. 1999, 99, 1689-1746.DOI: $10.1021 / \mathrm{cr} 9800659$

39. Majoral, J. P.; Caminade, A. M. Chem. Rev. 1999, 99, 845-880. DOI: $10.1021 / \mathrm{cr} 970414$

40. Vanherck, K., Koeckelberghs, G., Vankelecom, I. F. Prog. Poly. Sci.2013, 38, 874-896. DOI: $10.1016 /$ j.progpolymsci.2012.11.001

41. Abbasi, E.; Aval, S. F.; Akbarzadeh, A.; Milani, M.; Nasarbadi, H. T.; Joo, S. W.; Hanifehpour, Y.; Kazem, N.-K.; Roghiyeh, P.-S. Nan. Res. Lett. 2014, 9, 1-10.

DOI: $10.10 .1186 / 1556-276 X-9-247$
42. Caminade, A. M.; Ouali, A.; Laurent, R.; Turrin, C. O.; Majoral, J. P. Chem. Soc. Rev. 2015, 44, 3890-3899.

DOI: $10.1039 / \mathrm{C} 4 \mathrm{CS} 00261 \mathrm{~J}$.

43. Ornelas, C. Macromol. Chem. Phys. 2016, 217, 149-174. DOI: $10.1002 / \mathrm{macp} .201500393$

44. Li, W. S.; Kim, K. S.; Jiang, D. L.; Suna, Y.; Aida, T. J. Am. Chem. Soc. 2005, 127, 7700-7702.

DOI: $10.1021 / \mathrm{ja} 0513335$

45. Joralemon, J. M.; O’Reilly, R. K.; Matson, J. B.; Nugent, A. K.; Hawker,C. J.; Wooley, K. L. Macromolecules. 2005, 38, 5436-5443.

DOI: $10.1021 / \mathrm{ma} 050302 \mathrm{r}$

46. Fang, Z.; Teo, T. L.; Cai, L.; Lai, Y. H.; Samoc, A.; Samoc, M. Org. Lett. 2009, 11, 1-4.

DOI: $10.1021 / \mathrm{ol} 801238 \mathrm{n}$

47. Aoi, K.; Itoh, K.; Okada, M. Macromolecules.1997, 30, 80728074.

DOI: $10.1021 / \mathrm{ma} 961397 \mathrm{n}$.

48. Aoi, K.; Motoda, A.; Ohno, M.; Tsutsumiuchi, K.; Okada, M.; Imae, T. Polym. J.1999, 31, 1071-1078.

DOI: $10.1295 /$ polymj.

49. Kozaki, M.; Tujimura, H.; Suzuki, S.; Okada, K. Tetrah. Lett.2008, 49, 2931-2934. DOI: $10.1016 /$ j.tetlet.2008.03.008

50. Tripathy, S.; Das, M. K. J. App. Pharm. Sci. 2013, 3, 142-149. DOI: $10.7324 /$ JAPS.2013.3924

51. Caminade, A. M.; Laurent, R.; Nicot B. D.; Majoral,J. P. New J. Chem. 2012, 36, 217-226.

DOI: $10.1039 / \mathrm{C} 1 \mathrm{NJ} 20458 \mathrm{~K}$

52. Newkome, G. R.; Yao, Z. Q.; Baker, G. R.; Gupta, K. J. Org. Chem. 1985, 50, 2003-2004.

DOI: $10.1021 /$ jo00211a052

53. Walter, M. V.; Malkoch, M. Chem. Soc. Rev. 2012, 41, 45934609.

DOI: $10.1039 / \mathrm{C} 2 \mathrm{CS} 35062 \mathrm{~A}$

54. Jee, J.-A.; Spagnuolo, L. A.; Rudick, J. G. Org. Lett. 2012, 13, 3292-3295. DOI: $10.1021 / \mathrm{ol} 301263 \mathrm{v}$

55. Caminade, A. M.; Majoral, J. P. Molecules, 2016, 21, 538. DOI: $10.3390 /$ molecules21040538.

56. Morikawa, A. Molecules. 2016, 21, 219. DOI:10.3390/molecules21020219.

57. Abbassi, L.; Chabre, Y. M.; Kottari, N.; Arnold, A. A.; André, S.; Josserand, J.; Gabiusb, H.-J.; Roy, R. Polym. Chem. 2015, 6, 7666-7683.

58. Wooley, .K. L.; Hawker, C. J.; Fréchet, J. M. J. J. Am. Chem. Soc. 1991, 113, 4252-4261.

DOI: $10.1021 / \mathrm{ja} 00011 \mathrm{a} 031$.

59. Xu, Z. F.; Kahr, M.; Walker, K. L.; Wilkins, C. L.; Moore, J. S. J. Am. Chem. Soc. 1994, 116, 4537-4550.

DOI: $10.1021 / \mathrm{ja} 00090 \mathrm{a} 002$

60. Kawaguchi, T.; Walker, K. L.; Wilkins, C. L.; Moore, J. S. J. Am. Chem. Soc. 1995, 117, 2159-2165.

DOI: $10.1021 / \mathrm{ja} 00113 \mathrm{a} 005$.

61. Malkoch, M.; Malmstrom, E.; Hult, A. Macromolecules, 2002, 35, 8307-8314.

DOI: $10.1021 / \mathrm{ma} 0205360$

62. Hawker C. J; Chu F. Macromolecules, 1996, 29, 4370-4380. DOI: $10.1021 / \mathrm{ma9516706}$

63. Barany, G.; Merrifield , R. B. J. Am. Chem. Soc. 1977, 99, 7363-7365.

DOI: $10.1021 / \mathrm{ja} 00464 \mathrm{a} 050$

64. Spindler, R.; Fréchet, J. M. J. J. Chem. Soc. Perkin Trans. 1, 1993, 8, 913-918.

DOI: $10.1039 / \mathrm{P} 19930000913$.

65. Kempe, K.; Krieg, A.; Becer, C. R.; Schubert, U. S.Chem. Soc. Rev. 2012, 41, 176-191.

DOI: $10.1039 / \mathrm{c} 1 \mathrm{cs} 15107 \mathrm{j}$.

66. Kottari, N.; Chabre, Y. M.; Shiao,T. C.; Rej, R.; Roy, R. Chem. Commun. 2014, 50, 1983-1985.

DOI: $10.1039 / \mathrm{c} 3 \mathrm{cc} 46633 \mathrm{~g}$

67. Lowe, A. B. Polym. Chem. 2010, 1, 17-36.

DOI: $10.1039 / \mathrm{b} 9$ py00216b

68. Yamakawa, Y.; Ueda, M.; Takeuchi, K. Asai, M.J. Polym. Sci. Part A: Polym. Chem.1999, 37, 3638-3645. 
DOI: $10.1002 /($ SICI)1099-0518(19990915)37:18<3638::AIDPOLA12>3.0.CO;2-F

69. Lundberg, P.; Hawker, C. J.; Hult, A.; Malkoch, M. Macromol. Rapid Commun, 2008, 29, 998-1015.

DOI: $10.1002 / \mathrm{marc} .200800181$

70. Rannard, S. P. Davis, N. J. J. Am. Chem. Soc.2000, 122, 11729 11730.

DOI: $10.1021 / \mathrm{ja} 002613 \mathrm{~h}$

71. Malkoch, M.; Schleicher, K.; Drockenmuller, E.; Hawker, C. J.; Russell, T. P.; Wu, P.; Fokin, V. V. Macromolecules. 2005, 38, 3663-3668

DOI: $10.1021 / \mathrm{ma} 047657 \mathrm{f}$

72. Newkome, G. R.; Shreiner, C. D. Polymer. 2008,49, 1-173.

DOI:10.1016/j.polymer.2007.10.021.

73. Tschierske, C. Chem. Soc. Rev.2007, 36, 1930-1970. DOI: $10.1039 / \mathrm{B} 615517 \mathrm{~K}$

74. Buathong, D. S. W.; Bury, I.; Guillon, I. D. Chem. Soc. Rev.2007, 36, 1495-1513. DOI: $10.1039 / \mathrm{B} 605531 \mathrm{C}$

75. Marcos, M.; Rapún, R. M.; Omenat, A.; Serrano, J. L. Chem. Soc. Rev. 2007, 36, 1889-1901.

DOI: $10.1039 / \mathrm{B} 611123 \mathrm{H}$

76. Roy, R.; Shiao, T. C. Chem. Soc. Rev. 2015, 44, 3924-3941. DOI: $10.1039 / \mathrm{C} 4 \mathrm{CS} 00359 \mathrm{D}$.

77. Yu, Q.; Liu, J.; Chen, D.; Wang, R. Polymer. 2015, 79, 179 186.DOI:10.1016/j.polymer.2015.10.026.

78. Xiao, F.-X.; Pagliaro, M.; Xu, Y.-J.; Liu, B.Chem. Soc. Rev.2016, 45, 3088-3121.

79. DOI: $10.1039 / \mathrm{C} 5 \mathrm{CS} 00781 \mathrm{~J}$

80. Liu, X.; Zhou, J.; Tu, T.; Chen, C.; Cheng, Q.; Sengupta, K.; Haung, Y.; Li, H.; Liu, C.; Wang,Y.; Possocco, P.; Wang, M.; Cui, Q.; Giorgio, S.; Fermeglia, M.; Qu, F.; Pricl, S.; Shi, Y.; Liang, Z.; Rochhi, P.; Rossi, J. J.; Peng, L. Ang. Chem. Int. Ed. Engl.2014, 53, 11822-11827.

DOI: $10.1002 /$ anie.201406764

81. Hu, J.; Zhang, G.; Ge, Z.; Liu, S.Prog. Pol. Sci. 2014, 39,10961143

.DOI: $10.1016 /$ j.progpolymsci.2013.10.006.

82. Fan, W.; Sun, B.; Ma, J.; Li, X.; Tan, H.; Xu. L. Chem. A Eur. J.2015, 21, 12947-12959. DOI: $10.1002 /$ chem. 201501282

83. Hannes P. L.; Su, G. Y.; Shang, M.; Hessel, V.; Luque, R.; Noël, T.Chem. Soc. Rev.2016, 45, 83-117.

DOI: $10.1039 / \mathrm{C} 5 \mathrm{CS} 00447 \mathrm{~K}$.

84. Deraedt, C.; Pinaud, N.;Astru, D.J. Am. Chem. Soc.2014, 136 , 12092-12098. DOI: $10.1021 /$ ja5061388.

85. Bahrami, K.; Arabi. M. S.New J. Chem., 2016, 40, 3447-3455. DOI: $10.1039 / \mathrm{C} 5 \mathrm{NJ} 03219 \mathrm{~A}$.

86. Duan, H.; Wang, D.; Li, Y.Chem. Soc. Rev.2015, 44, 5778-5792. DOI: $10.1039 / \mathrm{C} 4 \mathrm{CS} 00363 \mathrm{~B}$.

87. Gawande, M. B.; Goswami, A.; Asefa, T.; Guo, H.; Biradar, A. V.; Peng, D. L;. Zboril, R.; Varma, R. S.Chem. Soc. Rev. 2015, 44, 7540-7590. DOI: $10.1039 / \mathrm{C} 5 \mathrm{CS} 00343 \mathrm{~A}$.

88. Caminade, A. M. Chem. Soc. Rev. 2016. DOI: $10.1039 / \mathrm{c} 6 \mathrm{cs} 00074 \mathrm{f}$.

89. Chen, G.; Roy, I.; Yang, C.; Prasad, P. N.Chem. Rev.2016, 116 2826-2885.

DOI: $10.1021 /$ acs.chemrev.5b00148.

90. Medina, S. H.; El-Sayed, M. E. H. Chem. Rev.2009, 109, 3141-3157.

DOI: $10.1021 / \mathrm{cr} 900174$

91. Kesharwani, P.; Jain, K.; Jain, N. K. Dendrimer as nanocarrier for drug delivery. Prog. Poly. Sci.2014, 39, 268-307. DOI: $10.1016 /$ j.progpolymsci.2013.07.005

92. Parajapati, S. K.; Maurya, S. D.; Das, M. K.; Tilak, V. K.; Dhakar, R. C.J. Drug Deliv. \& Therap.2016, 6, 67-72. DOI: $2250-1177$.

93. Karimi, M.; Ghasemi, A.; Zangabad, P. S.; Rahighi, R.; Basri, S M. M.; Mirshekari, H.; Bozorgomid, M. Z. S.; Ghosh, M.; Beyzavi, D. A.; Vaseghi, A.; Aref, A. R.; Haghani, L.; Bahrami, S.; Hamblin,M. R.Chem. Soc. Rev.2016, 45, 1457-1501. DOI: $10.1039 / \mathrm{C} 5 \mathrm{CS} 00798 \mathrm{D}$.

DOI: $10.1039 / \mathrm{C} 2 \mathrm{CS} 35306 \mathrm{G}$.

94. Liu, K.; Xu, Z.; Yin, M. Prog. Poly. Sci.2015, 46, 25-54.
DOI: $10.1016 /$ j.progpolymsci.2014.11.005

95. Dichtel, W. R.; Hecht, S.; Fréchet, J. M. J. Org. Lett. 2005, 20, 4451-4454.

DOI: $10.1021 / \mathrm{ol} 0516824$.

96. Astruc, D.; Ruiz, J. Tetrah. 2010, 66, 1769-1785.

DOI: $10.1016 /$ j.tet.2009.11.116.

97. Astruc, D.; Ornelas, C.; Ruiz, J. Chem. Eur. J. 2009, 15, 8936-8944.

DOI: $10.1002 /$ chem.200901294.

98. Ambade, A. V.; Chen, Y.; Thayumanavan, S. New J. Chem. 2007, 31, 1052-1063.

DOI: $10.1039 / \mathrm{B} 617628 \mathrm{C}$

99. Lehn, J. M. Prog. Polym. Sci. 2005, 30, 814-831.

DOI: $10.1016 /$ j.progpolymsci.2005.06.002

100. Maity, P.; Yamazoe, S.; Tsukuda, T. ACS Catal., 2013, 3, 182-185. DOI: $10.1021 / \mathrm{cs} 3007318$

101. Blanco, V.; Leigh, D. A.; Marcos, V.Chem. Soc. Rev.2015, 44, 5341-5370.DOI: $10.1039 / C 5 C S 00096 C$

102. Feng, C. L.; Zhong, X. H.; Steinhart, M. Caminade, A. M ; Majoral, J. P.; Knoll, W. Small. 2008, 4, 566-571.

DOI: $10.1002 / \mathrm{smll} .200700453$

103. Tang, Y. H.; Huang, A. Y.; Chen, P. Y.; Chen, H. T.; Kao, C. L. Curr Pharm Des. 2011, 22, 2308-2330.

104. Taranekar, P.; Fulghum, T.; Patton, D.; Ponnapati, R..; Clyde, G.; Advincula, R. J. Am. Chem. Soc. 2007, 129, 12537-12548. DOI: $10.1021 / \mathrm{ja} 074007 \mathrm{t}$.

105. Bhattacharya, P.; Kaifer, A. E. J. Org. Chem. 2008, 73, 5693-5698. DOI: $10.1021 /$ jo800953v.

106. Astruc, D. Oil Gas Sci. Technol. 2007, 62, 787-797. DOI: org/10.2516/ogst:2007055.

107. Ballauff, M.; Likos, C. N. Angew. Chem. Int. Ed. 2004, 43 2998-3020. DOI: $10.1002 /$ anie.200300602.

108. Balzani, V.; Ceroni, P.; Juris, A.; Venturi, M.; Campagna, S.; Puntoriero, F.; Serroni, S. Coord. Chem. Rev. 2001,545,219-221. DOI: $10.1016 / \mathrm{S} 0010-8545(01) 00351-4$.

109. Ceroni, P.; Bergamini, G.; Marchioni, F.; Balzani, V Luminescence as a tool to investigate dendrimer properties.Prog. Polym. Sci. 2005, 30, 453-473.

DOI: $10.1016 /$ j.progpolymsci.2005.01.003.

110. Chabre, Y. M.; Roy, R.; Horton, D.; Diego, C. A. S. In Advances in Carbohydrate Chemistry and Biochemistry Ed. Elsevier. 2010, 63, 165-393.

DOI: $10.1016 / \mathrm{S} 0065-2318(10) 64005-\mathrm{X}$.

111. Marturano, V.; Cerruti, P.; Carfagna, C.; Giamberini, M.; Tylkowski, B.; Ambrogi, V. Polymer. 2015, 70, 222-230. DOI: $10.1016 /$ j.polymer.2015.05.059.

112. Dongen, V.; De Hoog, S. F. M.; Peters, H. P.; Nallani, R. J. R.; Nolte, M.; Van, R. J. M.; Hest, J. C. M. Chem. Rev. 2009, 109, 6212-6274. DOI: $10.1021 / \mathrm{cr} 900072 \mathrm{y}$.

113. Kevwitch, R. M.; McGrath, D. V. New J. Chem. 2007, 31, 13321336. DOI: $10.1039 / \mathrm{B} 617289 \mathrm{~J}$

114. Sun, X.; Wang, Y.; Lei, Y.Chem. Soc. Rev.2015, 44, 8019-8061. DOI: $10.1039 / \mathrm{C} 5 \mathrm{CS} 00496 \mathrm{~A}$.

115. Lowe, A. B. Polymer. 2014, 55,5517-5549.

DOI: $10.1016 / \mathrm{j}$. polymer.2014.08.015.

116. Gawande, M. B.; Goswami, A.; Asefa, T.; Guo, H.; Biradar, A. V.; Peng, D.-L.; Zboril, R.; Varma, R. S.Chem. Soc. Rev.2015, 44,7540-7590. DOI: $10.1039 / \mathrm{C} 5 \mathrm{CS} 00343 \mathrm{~A}$

117. Gupta, U.; Agashe, H. B.; Asthana, A.; Jain, N. K.Biomacromolecules. 2006, 7, 649-658. DOI: $10.1021 / \mathrm{bm} 050802 \mathrm{~s}$

118. Sangeetha, N. M.; Maitra, U. Chem. Soc. Rev. 2005, 34, 821-836. DOI: $10.1039 / \mathrm{B} 417081 \mathrm{~B}$.

119. Yang, X.; Zhou, G.; Wong, W.-Y.Chem. Soc. Rev.2015, 44, 8484 8575.

DOI: $10.1016 /$ j.polymer.2015.09.073

120. Hwang, S. H.; Moorefield, C. N.; Newkome, G. R.Chem. Soc. Rev. 2008, 37, 2543-2557. DOI: $10.1039 / \mathrm{B} 803932 \mathrm{C}$

121. Xu, F.; Kim, H. U.; Kim, J.-H.; Jung, B. J.; Grimsdale, A. C.; Hwang, D.-H. Prog. Polym. Sci.2015, 47, 92-121. DOI: $10.1016 /$ j.progpolymsci.2015.01.005 
122. Liu, Y.; Guan, Y.; Zhang, Y. Polymer. 2015, 77, 366-376. DOI: $10.1016 /$ j.polymer.2015.09.073

123. Yang, X.; Zhou, G.; Wong, W.-Y.Chem. Soc. Rev.2015, 44, 84848575 DOI: $10.1039 / \mathrm{C} 5 \mathrm{CS} 00424 \mathrm{~A}$

124. Zhang, W.; Zhu, S.; Luque, R.; Han, S.; Hu, L.; Xu,G. Chem. Soc. Rev.2016, 45, 715-752. DOI: $10.1039 / \mathrm{C} 5 \mathrm{CS} 00297 \mathrm{D}$.

125. Verwilst, P.; Park, S.; Yoon, B.; Kim, J. S.Chem. Soc. Rev.2015, 44,1791-1806. DOI: $10.1039 / \mathrm{C} 4 \mathrm{CS} 00336 \mathrm{E}$

126. Han, H.; Zhang, S.; Wang, Y.; Chen, T.; Jin, Q.; Chen, Y.; Li, Z.; Ji, J. Polymer. 2016, 82, 255-261. DOI: $10.1016 /$ j.polymer.2015.11.022.

127. Lockman, J. W.; Paul, N. M.; Parquette, J. R. Prog. Polym. Sci. 2005, 30, 423-452. DOI: $10.1016 /$ j.progpolymsci.2005.01.012

128. Cho, M. J.; Choi, D. H.; Sullivan, P. A.; Akelaitis, A. J. P.; Dalton, L. R. Prog. Polym. Sci. 2008, 33, 1013-1058. DOI: $10.1016 /$ j.progpolymsci.2008.07.007.

129. Tomczak, N.; Janczewski, D.; Han, M.; Vancso, G. J. Prog. Polym. Sci., 2009, 34, 393-430. DOI: $10.1016 /$ j.progpolymsci.2008.11.004.

130. Li, D.; Chen, Y.; Liu, Z. Chem. Soc. Rev.2015, 44, 8097-8123. DOI: $10.1039 / \mathrm{C} 5 \mathrm{CS} 00013 \mathrm{~K}$

131. Grinstaff, M. W. J. Polym. Sci. Part A: Polym. Chem. 2008, 46, 383-389. DOI:10.1002/pola.22525

132. Weinert, C. S. Dalton Trans. 2009, 30, 1691-1699. DOI: $10.1039 / \mathrm{B} 816067 \mathrm{H}$

133. Simenek, E. E.; Abdou, H.; Lalwani, S.; Lim, J.; Mintzer, M.; Venditto, V. J.; Vittur, B. Proc. R. Soc. A. 2010, 466, 1445-1460. DOI: $10.1098 /$ rspa.2009.0108.

134. Bansal, K. K.; Kakde, D.; Gupta, U.; Jain, N. K. J. Nanoscience and Nanotechnology. 2010, 10, 8395-8404. ISSN: 1533-4899

135. Li, W. S.; Aida, T. Chem. Rev. 2009, 109, 6047-6076. DOI: $10.1021 / \mathrm{cr} 900186 \mathrm{c}$

136. Wu, T.; Shi, J.; Li, C.; Song, J.; Xu, L.; Wang, H. Org. Lett. 2013, $15,354-357$. DOI: $10.1021 / \mathrm{ol} 303300 \mathrm{w}$

137. Hadad, C.; Martínez, J. C. G.; López,R. J.J. Org. Chem. 2012, 77, 6223-6230. DOI: $10.1021 /$ jo301054w

138. Cumpstey, N.; Bera, R. N.; Burn, P. L.; Samuel, I. D. W. Macromolecules. 2005, 38, 9564-9570.

DOI: $10.1021 / \mathrm{ma} 050609 \mathrm{q}$

139. Roland, B. K.; Flora, W. H.; Selby, H. D.; Armstrong, N. R.; Zheng, Z. J. Am. Chem. Soc. 2006, 128, 6620-6625. DOI: $10.1021 / \mathrm{ja} 057548 \mathrm{w}$

140. Rajakumar, P.; Ayyavu, T.; Raja, S.; Ganesan, S.; Maruthamuthu, P. Tetrah. Lett. 2012, 53, 1139-1143. DOI: $10.1016 /$ j.tetlet.2011.12.098.

141. Lee, C. C.; Leung, M. K.; Lee, P. Y.; Chiu, T. L.; Lee, H.; Chun, J.; Liu, C.; Chou, P. T. Macromolecules. 2012, 45, 751-765. DOI: $10.1021 / \mathrm{ma} 202433 \mathrm{y}$.

142. El-Khouly, M. E.; Lee, S. H.; Kay, K. Y.; Fukuzumi, S. New J. Chem. 2013, 37, 3252-3260. DOI: $10.1039 / \mathrm{C} 3 \mathrm{NJ} 00770 \mathrm{G}$.

143. Cha, S. W.; Choi, S. H.; Kim, K.; Jin, J. I. J. Mater. Chem. 2003, 13, 1900-1904.DOI: 10.1039/B302568C

144. Zhao, Z.; Li, J. H.; Chen, X.; Wang, X.; Lu, P.; Yang, Y. J. Org. Chem. 2009, 74, 383-395.

DOI: $10.1021 /$ jo802237c.

145. Wang, J. L.; Zhou, Y.; Li, Y.; Pei, J. J. Org. Chem. 2009, 74, 7449-7456

146. DOI: $10.1021 /$ jo901539a.

147. Rajakumar, P.; Kalpana, V.; Ganesan, S.; Maruthamuthu, P.Tetrah. Lett.2011, 52, 5812-5816. DOI: $10.1016 /$ j.tetlet.2011.08.126.

148. Thirumurugan, P.; Matosiuk, D.; Jozwiak, K. Chem. Rev. 2013, 113, 4905-4979. DOI: $10.1021 / \mathrm{cr} 200409 \mathrm{f}$

149. Majoral, J. P.; Caminade, A. M.Chem. Rev. 1999, 99, 845-880. DOI: $10.1021 / \mathrm{cr} 9600971$

150. Haridas, V.; Kashmiri, L.; Yogesh, K. S. Tetrah. Lett.2007, 48, 4719-4722.
DOI: $10.1016 /$ j.tetlet.2007.05.023

151. Vieyres, A.; Lam, T.; Gillet, R.; Franc, G.; Castonguay, A.; Kakkar, A. Chem. Commun. 2010, 46, 1875-1877. DOI: $10.1039 / \mathrm{B} 924888 \mathrm{~A}$

152. Freeman, A. W.; Fréchet, J. M. J. Org. Lett. 1999, 1, 685-687. DOI: $10.1021 / 019907724$

153. Killops, K. L.; Campos, L. M.; Hawker, C. J. J. Am. Chem. Soc 2008, 130, 5062-5064.

DOI: $10.1021 / \mathrm{ja} 8006325$

154. Montanez, M. I.; Campos, L. M.; Antoni, P.; Hed, Y.; Walter, M. V.; Krull, B. T.; Khan, A.; Hult, A.; Hawker, C. J.; Malkoch, M. Macromolecules. 2010, 43, 6004-6013. DOI: $10.1021 / \mathrm{ma} 1009935$

155. Morgenroth, F.; Reuther, E.; Mullen, K..Angew. Chem. Int. Ed. Engl. 1997, 36, 631-634.

DOI: 10.1002 /anie. 199706311

156. Bergamini,G.; Ceroni,P.; Maestri,M.; Balzani, V.; Lee, S. K.; Vogtle,. F. Photochem. Photobiol. Sci.2004, 3, 898-905. DOI: $10.1039 / \mathrm{B} 408659 \mathrm{G}$.

157. Morgenroth, F.; Reuther, E.; Müllen, K. Ange.Chem. Int. Ed. 1997, 36, 631-634

DOI: 10.1002 /anie. 199706311

158. Fang, Z. Teo, T. L.; Cai, L.; Lai, Y. H.; Samoc, A.; Samoc, M. Org. Lett. 2009, 11, 1-4. DOI: $10.1021 / \mathrm{ol} 01238 \mathrm{n}$;

159. Gray, V.; Dzebo, D.; Lundin, A.; Alborzpour, J.; Abrahamsson, M.;Albinsson, B.; Moth-Poulsen, K.J. Materials Chem. C. 2015, 42, 11111-11121.

DOI: $10.1039 / \mathrm{C} 5 \mathrm{TC} 02626 \mathrm{~A}$

160. Deb, S. K.; Maddux, T. M.; Yu, L. P. J. Am. Chem. Soc., 1997 119, 9079-9080. DOI: $10.1021 / \mathrm{ja} 971790$ o

161. Kushwaha, D.; Tiwari, V. K. J. Org. Chem.2013,78, 81848190.DOI: 10.1021/jo4012392.

162. Appelhans, D.; Maculewicz, B. K.; Janaszewska, A.; Lazniewskab, J.; Voit, B. Chem. Soc. Rev. 2015, 44, 3968-3996. DOI: $10.1039 / \mathrm{c} 4 \mathrm{cs} 00339 \mathrm{j}$

163. Lakshminarayanan, A.; Ravi, V. K.; Tatineni, R.; Rajesh, Y. B. R. D.; Maingi, V.; Vasu, K. S.; Madhusudhan, N.;.Maiti, P. K.; Sood, A. K.; Das, S.; Jayaraman, N. Bioconjugate Chem. 2013, 24, 1612-1623. DOI: $10.1021 / \mathrm{bc} 400247 \mathrm{w}$.

164. Qamhieh, K.; Nylander, T.; Black, C. F.; Attard, G. S.; Dias, R. S.; Ainalem, M. L.Phys. Chem.Chemical Physics. 2014, 16 , 13112-13122.

DOI: $10.1039 / \mathrm{C} 4 \mathrm{CP} 01958 \mathrm{~J}$

165. Holler, M.; Nierengarten, J. F. Aust. J. Chem. 2009, 62, 605-623. DOI: org/10.1071/CH09163.

166. Blunt, J. W.;Copp, B. R.; Keyzers, R. A.; Munroa, M. H. G.; Prinsep, M. R. Nat. Prod. Rep. 2016, 33, 382-386. DOI: $10.1039 / \mathrm{b} 805113 \mathrm{p}$

167. Hager, A.; Vrielink, N.; Hager, D.; Lefranc, J.; Trauner, D.; Nat. Prod. Rep. 2016, 33, 491-522. DOI: $10.1039 / \mathrm{c} 5 \mathrm{np00096 \textrm {c }}$

168. Henry, R. J. Bacteriological reviews. 1943, 7, 344-349. ISSN 2347-9531.

169. Otten, H., 1986, 17,689-690. DOI: $10.1093 / \mathrm{jac} / 17.6 .689$

170. McCormack, P. L. Drugs.2011, 71, 2457-2489. DOI: $10.2165 / 11208240-000000000-00000$

171. Tóth, É.; Pubanz, D.; Vauthey, S.; Helm, L.; Merbach, A. E. Chem. Eur. J. 1996, 2, 1607-1615. DOI: $10.1002 /$ chem.19960021220

172. Wiener, E. C.; Auteri, F. P.; Chen, J. W.; Brechbiel, M. W.; Gansow, O. A.; Schneider, D. S.; Belford, R. L.; Clarkson, R. B.; Lauterbur, P. C. J. Am. Chem. Soc. 1996, 118, 7774-7782. DOI: $10.1021 /$ ja9536126

173. Valério, C.; Fillaut, J.-L.; Ruiz, J.; Guittard, J.; Blais, J.-C.; Astruc, D. J. Am. Chem. Soc. 1997, 119, 2588-2589. DOI: $10.1021 / \mathrm{ja} 964127 \mathrm{t}$

174. Ambure, P.; Roy, K. Understanding the structural requirements of cyclic sulfone hydroxyethylamines as hBACE1 inhibitors against $\mathrm{A} \beta$ plaques in Alzheimer's disease: a predictive QSAR approach. RSC Adv., 2016, 6, 28171-28186.

DOI: $10.1039 /$ C6RA04104C 
175. Villemagne, B.; Flipo, M.; Blondiaux, N.; Crauste, C.; Malaquin, S.; Leroux, F.; Piveteau, C.; Villeret, V.; Brodin, P.; Villoutreix, B. O.; Sperandio, O.; Soror, S. H.; Wohlkönig, A.; Wintjens, R.; Deprez, B.; Baulard, A. R.; Willand, N. J. Med. Chem. 2014, 57, 4876-4888.

DOI: $10.1021 / \mathrm{jm} 500422 \mathrm{~b}$

176. Searles, S.; Nukina. S.Chem. Rev.1959, 6, 1077-1103. DOI: $10.1021 / \mathrm{cr} 50030 \mathrm{a} 004$.

177. Tabrizian, E.; Amoozadeh, A.; Rahmani, S. RSC Adv. 2016, 6, 21854-21864. DOI: $10.1039 / \mathrm{C} 5 \mathrm{RA} 20507 \mathrm{G}$.

178. Li, G.; Zhao, C.; Cui, Y.; Rong, T.; Zhua, C.; Na, H. RSC. Adv. 2016, 6, 23025-23032.

DOI: $10.1039 / \mathrm{C} 6 \mathrm{RA} 02321 \mathrm{E}$

179. Lin, C. X.; Zhuo, Y. Z.; Lai, A. N.; Zhang, Q. J.; Zhu, A. M.; Liu, Q. L.Rsc. Adv. 2016, 6, 17269- 17279. DOI:10.1039/C5RA22774G

180. Jiang, H.; Wang, R.; Farhan, S.; Zheng, S.2015, 64, 17941800.DOI: $10.1002 /$ pi.4982.

181. Syrgiannis, Z.; La Parola, V.; Hadad, C.; Lucio, M.; Vazquez, E.; Giacalone, F.; Prato, M. Ang.Chem. Int. Ed., 2013, 52, 6480-6483. DOI: $10.1002 /$ anie.201207362.

182. Megia-Fernandez, A.; Hernandez-Mateo, F.; Santoyo-Gonzalez, F. Org. \& Biom. Chem. 2013, 11, 2586-2596.

DOI: $10.1039 / \mathrm{C} 3 \mathrm{OB} 27209 \mathrm{E}$.

183. Yoshio, M.; Konishi, R.; Sakamoto, T.; Kato, T.New J. Chem. 2013, 37, 143-147. DOI: $10.1039 / \mathrm{C} 2 \mathrm{NJ} 40681 \mathrm{~K}$.

184. Osano, K.; Turner, S. R.Journal of Polym. Sci., Part A: Polym.Chem. 2008, 46, 958-969.

DOI: $10.1039 /$ c6py00127k.

185. Adam, M. W.; Takahiro, M.; Kazushi, K. Polym. Chem. 2016, 7 , 2389-2394.

DOI: $10.1039 /$ c6py00127k.

186. Takahiro, M.; Junpei, M.; Soichi, M.; Masahiro, W.; Kenji, M. A. RSC. Adv. 2015, 5, 50082-50086.

DOI: $10.1039 / \mathrm{C} 5 \mathrm{RA} 05698 \mathrm{E}$

187. Xundao, L.; Gao, H.; Chen, X.; Hu, Y.; Li, H.; Zhang,Polym. Chem. 2016, 7, 2904-2912.

DOI: $10.1039 / \mathrm{C} 6 \mathrm{PY} 00036 \mathrm{C}$.

188. Jingmei, X., Zhe, W.; Huixuan, Z.; Hongzhe, N.; Xueyan, L.; Bingxin, L.; RSC. Adv. 2016, 6, 27725-27737. DOI: $10.1039 / C 5 R A 24894 A$.

189. Quanbing, M.; Yuan, M.; Xin, J.; Xinyuan, Z. Macro. Chem. Phys. 2016. Mol. Syst. Des. Eng.

DOI: $10.1039 / \mathrm{c} 5 \mathrm{me} 00015 \mathrm{~g}$

190. Ahmed, M.; Rahman, A.; Schweizer, B. W.; Lukin, O.; Zhang, A.; Schlüter, A. D. Macromol. Chem. Phys. 2010, 211, 1538-1549. DOI: $10.1002 / \mathrm{macp} .201000031$

191. Gindt, B. P. Abebe, D. G.; Tang, Z. J.; Lindsey, M. B.; Chen, J.; Elgammal, R. A.; Zawodzinski, T. A.; Fujiwara, T. J. Mater. Chem. A. 2016, 4, 4288-4295.

DOI: $10.1039 /$ C6TA00698A.

192. Astruc, D.; Boisselier, E.; Ornelas, C. Chem. Rev. 2010, 110, 1857-1959.

DOI: $10.1021 / \mathrm{cr} 900327 \mathrm{~d}$.

193. Archut, A.; Gestermann, S.; Hesse, R.; Kauffmann, C.; Vogtle, F. Synlett. 1998, 5, 546-548.

DOI: $10.1016 /$ j.polymer.2007.10.021

194. Hahn, U.; Gorka, M.; Vogtle, F.; Vicinelli, V.; Ceroni, P.; Maestri, M.; Balzani, V. Angew. Chem. Int. Ed. 2002, 41, 3595-3598. DOI: $10.1002 / 1521-3773(20021004) 41: 19<3595:: A I D-$ ANIE3595>3.0.CO;2-B.

195. Felder, T.; Schalley, C. A.; Fakhrnabavi, H.; Lukin, O. A. Chem. Eur. J. 2005, 11, 5625-5636 DOI: $10.1002 /$ chem. 200401236

196. Mekelburger, H. B; Rissanen, K.; Vögtle, F.Chem Ber., 1993, 126, 1161-1169.

DOI: $10.1002 /$ cber.19931260516.

197. Mekelburger, H. B; Vögtle, F. Supramol Chem. 1993, 1, 187189.DOI: $10.1080 / 10610279308035159$.

198. Moors R.; Vögtle, F. Cascade molecules: building blocks, multiple functionalization, complexing units, photoswitches. In: Newkome GR, editor. Advances in dendritic macromolecules. Greenwich, Conn.: JAI. 1995, 41-71.
199. Vögtle, F.; Fakhrnabavi, H.; Lukin, O. Org. Lett. 2004, 6, 10751078.DOI: $10.1021 / \mathrm{ol} 030130 \mathrm{n}$

200. Vogtle, F.; Fakhrnabavi, H.; Lukin, O.; Muller, S.; Friedhofen, J. Eur. J. Org. Chem. 2004, 4717-4724.

DOI: $10.1002 /$ ejoc. 200400472

201. Lukin, O.; Gramlich, V.; Kandre, R.; Zhun, I.; Felder, T.; Schalley, C. A.J. Am. Chem. Soc. 2006, 128, 8964-8974.

DOI: $10.1021 / \mathrm{ja} 061606 \mathrm{~b}$

202. Lukin, O.; Schubert, D.; Müller, C.; Corda, M.; Kandre, R. J. Org. Chem., 2008, 73, 3562-3565. DOI: $10.1021 /$ jo800179m.

203. Schubert, D.; Corda, M.; Lukin,O.; Brusilowskij, B.; Fiskin, E.; Schalley, C. A. Eur. J. Org. Chem. 2008, 24, 4148-4156. DOI: $10.1002 /$ ejoc.200800408.

204. Vögtle, F.; Gorka, M.; Hesse, R.; Ceroni, P.; Maestri, M.; Balzani,V.Photochem. Photobiol. Sci., 2002, 1, 45-51. DOI: $10.1039 / \mathrm{B} 106813 \mathrm{~J}$

205. Vincinelli, V.; Ceroni, P.; Maestri, M.; Lazzari, M.; Balzani, V.; Lee, S. K. Org Biomol Chem. 2004, 2, 2207-2213. DOI: $10.1039 / \mathrm{b} 404463 \mathrm{k}$.

206. Bergamini, G.; Ceroni, P.; Balzani, V.; Villavieja, M. D. M.; Kandre, R.; Zhun, I. Chem. Phys. Chem 2006, 7, 1980-1984. DOI: $10.1002 /$ cphc. 200600259 .

207. Bergamini, G.; Ceroni, P.; Balzani, V.; Kandre, R.; Lukin, O.Chem. Phys. Chem. 2009, 10, 265-269.

DOI: $10.1002 / \mathrm{cphc} .200800597$

208. Taylor, P. C.; Wall, M. D.; Woodward, P. R. Tetrah. 2005, 61, 12314-22.

DOI: $10.1016 /$ j.tet.2005.09.103

209. Percec, V.; Barboiu, B.; Grigoras, C.; Bera, T. K. J. Am. Chem. Soc.2003, 125, 6503-6516. DOI: $10.1021 / \mathrm{ja} 034746 \mathrm{j}$.

210. Matsumura, S.; Hlil, A. R.; Hay, A. S. J. Polym Sci Part A Polym Chem. 2008, 46, 6365-6375.

DOI: $10.1002 /$ pola.22965.

211. Khanam, S.; Rai, S. K.; Verma, D;. Khanna, R. S.; Tewari, A. K.2016, 6, 56952-56962. DOI: $10.1039 /$ C6RA09929G

212. Ortega, P.;Serram, M.-J.; Samaniego, R.;dela Mata, F. J.;Gomez, R. A. M.; Fernandez, M.Org. Biomol. Chem.2009, 7, 30793085.DOI: $10.1039 / \mathrm{B} 900942 \mathrm{~F}$.

213. Pathak, A. K.; Pathaka,V.; Seitz, L.;.Gurcha, S. S.; Besra, G. S.; Riordan, J. M.; Reynolds, R. C.Bioorg. Med. Chem.2007, 15, 5629-5650. DOI: $10.1016 /$ j.bmc.2007.04.012

214. Amoresano, A.; Chiappetta, G.; Pucci, P.; D'Ischia, P. M.; Marino, G.Anal. Chem. 2007, 79, 2109-2108. DOI: $10.1021 / \mathrm{ac} 0620361$.

215. Hoffmann, K.; Genger, U. R.; Mix, R.; Friedrich, J. F.J. Fluoresc.2006, 16, 441-448. DOI: $10.1007 / \mathrm{s} 10895-006-0076-\mathrm{x}$.

216. O’Connor, N. A.; Sakata, S. T.; Huide, Z.; Shea, K. J.Org. Lett., 2006, 8, 1581-1584.

DOI: $10.1021 / 01060130 y$

217. Mure, M.; Kurtis, C. R.; Brown, D. R..; Rogers, M. S.; Tambyrajah, W. S.;Saysell, C.; .Wilmot, C. M.;Phillips, S. E. V.;Knowles, P. F.;Dooley, D. M.;McPherson, M. J. Biochemistry; 2005, 44, 15083-1594. DOI: $10.1021 / \mathrm{bi0479860.}$

218. Misra, A.; Mishra, S.; Misra, K.. Bioconjugate Chem.2004, 15, 638-646. DOI: $10.1021 / \mathrm{bc} 049976 \mathrm{~h}$.

219. Metivier, R.; Leray, I.; Valeur, B. A. Chem. Commun. 2003, 8 , 996-997. DOI: $10.1039 / \mathrm{B} 301323 \mathrm{E}$.

220. Ceroni, P.; Laghi, I.; Maestri, M.; Balzani, V.; Gestermann, S.; Gorka, M.; Vogtle, F. New J. Chem., 2002, 26, 66-73. DOI: $10.1039 / B 105497 J$.

221. Sanfrutos, J. M.;Fernandez, A. M.;Mateo, F. H.; Gonzalez, M. D. G.; Gonzalez, R. S.; Gonzalez, F. S.Org. Biomol. Chem.,2011, 9 , 851-864. DOI: $10.1039 / \mathrm{C} 0 \mathrm{OB} 00355 \mathrm{G}$

222. Carta, F.;.Osman, S. M.; Vullo, D.; Alothman, Z.; Supuran, C. T.Org. Biomol. Chem., 2015, 13, 6453-6457.

DOI: $10.1039 / \mathrm{c} 5$ ob00715a. 
223. Mañas, M. M.; Pleixats, R.; Sebastián, R. M.; Vallribera, A.; Roglans, A. J. Organomet. Chem., 2004, 689, 3669-3684. DOI:10.1016/j.jorganchem.2004.05.024.

224. Mañas, M. M.; Reichardt, C; Sebastián, R. M.; Barberá, J.; Serranob, J. L.; Sierra, T. J. Mater. Chem.2005, 15, 2210-2219. DOI: $10.1039 / \mathrm{b} 502561 \mathrm{c}$.

225. Hincapi, C. A.; Sebastián, R. M.; Barber, J.; Serrano, J. L.; Sierra, T.; Majoral, J. P.; Caminade, A. M. Chem. Eur. J. 2014, 20, 17047-17058.

DOI: $10.1002 /$ chem.201402539

226. Wu, W.; Xu, G.; Li, C.; Yu, G.; Liu, Y.; Ye, C.; Qin, J.; Li, Z. Chem. Eur. J. 2013, 19, 6874-6888. DOI: $10.1002 /$ chem. 201203567.

227. Sullivan, P. A.; Rommel, H.; Liao, Y.; Olbricht, B. C.; Akelaitis, A. J. P.; Firestone, K. A.; Kang, J. W.; Luo, J.; Davies, J. A.; Choi, D. H.; Eichinger, B. E.; Reid, P. J.; Chen, A.; Jen, A. K. Y.; Robinson, B. H.; Dalton, L. R.J. Am. Chem. Soc. 2007, 129, 7523-7530.

DOI: $10.1021 / \mathrm{ja} 068322 \mathrm{~b}$

228. Li, K.; Qu, J.; Xu, B.; Zhou, Y.; Liu, L.; Peng, P.; Tian, W. New J. Chem., 2009, 33,2120-2127. DOI: $10.1039 / \mathrm{b} 9 \mathrm{nj00236g.}$

229. Rajakumar, P.; Kalpana, V.; Ganesanb, S.; Maruthamuthu, P.New J. Chem. 2013, 37, 3692-3700.

DOI: $10.1039 / \mathrm{c} 3 \mathrm{nj} 00887 \mathrm{~h}$.

230. Zarco, M. M.; Titvinidze, G.; Martınez, J. C. G.; Lopez, J. R. J. Polym Sci Part A Polym Chem. 2016, 54, 69-80.

DOI: 10.1002/pola.27777

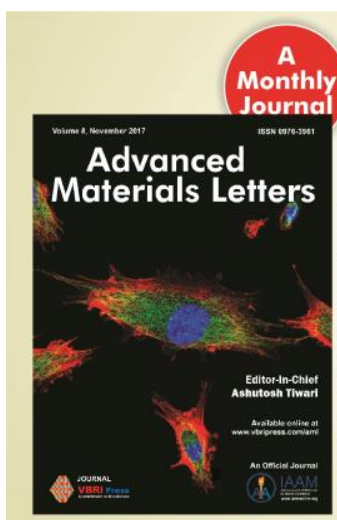

Copyright $\odot 2017$ VBRI Press AB, Sweden

\section{Publish}

your article in this journal

Advanced Materials Letters is an official international journal of International Association of Advanced Materials (IAAM, www.iaamonline.org) published monthly by VBRI Press AB from Sweden. The journal is intended to provide high-quality peer-review articles in the fascinating field of materials science and technology particularly in the area of structure, synthesis and processing, characterisation, advanced-state properties and applications of materials. All published articles are indexed in various databases and are available download for free. The manuscript management system is completely electronic and has fast and fair peer-review
process. The journal includes review article, research article, notes, letter to editor and short communications.

www.vbripress.com/aml 